\title{
Hybrid Moving Bed Biofilm Reactor for the biodegradation of benzotriazoles and hydroxy-benzothiazole in wastewater
}

Mazioti, Aikaterini A.; Stasinakis, Athanasios S.; Psoma, Aikaterini K.; Thomaidis, Nikolaos S.; Andersen, Henrik Rasmus

Published in:

Journal of Hazardous Materials

Link to article, DOI:

10.1016/j.jhazmat.2016.06.035

Publication date:

2017

Document Version

Peer reviewed version

Link back to DTU Orbit

Citation $(A P A)$ :

Mazioti, A. A., Stasinakis, A. S., Psoma, A. K., Thomaidis, N. S., \& Andersen, H. R. (2017). Hybrid Moving Bed Biofilm Reactor for the biodegradation of benzotriazoles and hydroxy-benzothiazole in wastewater. Journal of Hazardous Materials, 323(Part A), 299-310. https://doi.org/10.1016/j.jhazmat.2016.06.035

\section{General rights}

Copyright and moral rights for the publications made accessible in the public portal are retained by the authors and/or other copyright owners and it is a condition of accessing publications that users recognise and abide by the legal requirements associated with these rights.

- Users may download and print one copy of any publication from the public portal for the purpose of private study or research.

- You may not further distribute the material or use it for any profit-making activity or commercial gain

- You may freely distribute the URL identifying the publication in the public portal 


\title{
Hybrid Moving Bed Biofilm Reactor for the biodegradation of benzotriazoles and hydroxy-benzothiazole in wastewater
}

\author{
Aikaterini A. Mazioti ${ }^{a}$, Athanasios S. Stasinakis ${ }^{a, b^{*}}$, Aikaterini K. Psoma ${ }^{c}$, Nikolaos S. Thomaidis ${ }^{c}$, Henrik R. \\ Andersen $^{\mathrm{b}}$ \\ ${ }^{a}$ Department of Environment, University of the Aegean, 81100 Mytilene, Greece. *Corresponding author. Tel.: +30 22510 36257; fax: +30 22510 \\ 36206, astas@env.aegean.gr \\ ${ }^{\mathrm{b}}$ Department of Environmental Engineering, Technical University of Denmark, Miljøvej, B 113, 2800 Kgs. Lyngby, Denmark \\ 'Department of Chemistry, National and Kapodistrian University of Athens, Panepistimioupolis Zografou, 15771 Athens, Greece
}

-All target compounds were partially removed in hybrid moving bed biofilm reactor -5 compounds were removed mainly in $1^{\text {st }}$ stage, critical role of $2^{\text {nd }}$ stage for 4TTR - AS and biocarriers contribute to different extent to micropollutants biodegradation -HMBBR and low loaded MBBR are the most efficient systems for studied compounds - 22 biotransformation products were tentatively identified

\section{Hybrid Moving Bed Biofilm Reactor}
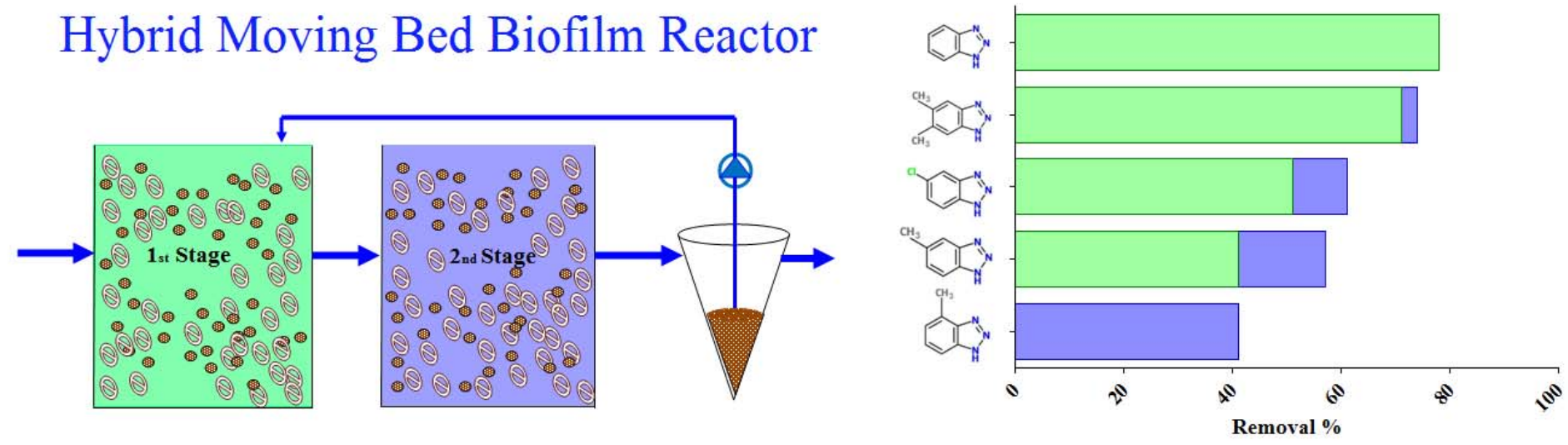


\begin{abstract}
A laboratory scale Hybrid Moving Bed Biofilm Reactor (HMBBR) was used to study the removal of five benzotriazoles and one benzothiazole from municipal wastewater. The HMBBR system consisted of two serially connected fully aerated bioreactors that contained activated sludge (AS) and K3-biocarriers and a settling tank. The average removal of target compounds ranged between $41 \%$ (4-methyl-1H-benzotriazole; 4TTR) and $88 \%$ (2hydroxybenzothiazole; OHBTH). Except for 4TTR, degradation mainly occurred in the first bioreactor. Calculation of biodegradation constants in batch experiments and application of a model for describing micropollutants removal in the examined system showed that AS is mainly involved in biodegradation of OHBTH, $1 \mathrm{H}$-benzotriazole (BTR) and xylytriazole (XTR), carriers contribute significantly on 4TTR biodegradation, while both types of biomass participate on elimination of 5-chlorobenzotriazole (CBTR) and 5-methyl-1H-benzotriazole (5TTR). Comparison of the HMBBR system with MBBR or AS systems from literature showed that the HMBBR system was more efficient for the biodegradation of the investigated chemicals. Biotransformation products of target compounds were identified using ultra highperformance liquid chromatography, coupled with a quadrupole-time-of-flight high-resolution mass spectrometer (UHPLC-QToF-MS). Twenty two biotransformation products were tentatively identified, while retention time denoted the formation of more polar transformation products than the parent compounds.
\end{abstract}

Keywords: micropollutants; biological treatment; sewage; kinetics; biotransformation; biofilm

\title{
Introduction
}

Growing demand for more efficient wastewater treatment is leading to new technologies for treatment as well as improvement of existing ones. Concerning biological treatment, the Hybrid Moving Bed Biofilm Reactor (HMBBR) is an approach that was introduced two decades ago for the first time in wastewater engineering [1]. The HMBBR is a combination of a typical activated sludge (AS) system with a Moving Bed Biofilm Reactor (MBBR), in which biofilm attached on biocarriers and AS flocs co-exist in the bioreactor, contributing to wastewater treatment. The main advantages of such a system compared to AS are the lower requirement for process volume, the increased nitrification capacity and the lower sludge load on the secondary clarifier [2]. Due to the above, HMBBR systems have been successfully used for upgrading of conventional AS systems $[3,4]$.

So far, only few studies have focused on the ability of HMBBR systems to remove micropollutants from wastewater. Falås et al. [5] examined the elimination of 20 micropollutants from a large scale HMBBR in Switzerland and reported that the attached growth biomass can contribute significantly to the removal of specific compounds in such systems. Escolà Casas et al. [6] investigated the removal of 26 pharmaceuticals in hospital wastewater by a 4 staged pilot treatment plant consisting of AS, HMBBR and MBBR reactors in series and reported biodegradation kinetics in different bioreactors. Finally, Sfaelou et al. [7] recently examined the effects and removal of phenanthrene in sequencing batch reactors containing AS and biocarriers. To the best of our knowledge, no other studies have been published on the removal of micropollutants in HMBBR systems.

Benzotriazoles (BTRs) and Benzothiazoles (BTHs) are two groups of micropollutants that occur in wastewater from domestic and industrial activities [8]. BTRs are found in corrosion-inhibiting products, cooling fluids, de-icing fluids and dishwashing detergents [9], while BTHs are used as vulcanization accelerators and stabilizers in the photo industry [10]. Both groups are highly soluble in water and highly polar, leading to their persistence in the water cycle $[11,12]$. The partial removal of some of them in AS systems has been documented in monitoring studies [13, 14, 15] and laboratory biodegradation experiments [16, 17]. Moreover, information on the biotransformation products of specific BTRs (1H-benzotriazole, BTR; 4-methyl1H-benzotriazole, 4TTR; 5-methyl-1H-benzotriazole, 5TTR) has been reported in activated sludge experiments $[16,18]$. In a recent study, Mazioti et al. [19] compared the ability of AS and pure MBBR systems to biodegrade six of these compounds (BTR; 4TTR; 5TTR; xylytriazole, XTR; 5-chlorobenzotriazole, CBTR; 2hydroxybenzothiazole, OHBTH) and reported that attached biomass had higher biodegradation potential compared to AS. To the best of our knowledge, no information is available on the removal of these compounds in HMBBR, on the contribution of co-existing types of biomass on their biodegradation and on the produced transformation by-products. 
The aim of this study was to investigate the potential of a laboratory scale HMBBR system, consisting of two bioreactors in series, to remove BTR, 4TTR, 5TTR, XTR, CBTR and OHBTH from domestic wastewater. Concentrations of target compounds in different points of the hybrid system were monitored and the observed removal efficiencies were compared with those reported in a previous study using AS and MBBR systems [19]. Biodegradation kinetics of the target compounds were also determined using AS and biocarriers from the HMBBR system and a model was applied to describe the contribution to micropollutants removal by different mechanisms (biodegradation, sorption) and by different types of biomass (sludge, biofilm). Finally, batch experiments were conducted and for the first time biotransformation products formed in a HMBBR reactor were tentatively identified.

\section{Materials and Methods}

\subsection{Analytical standards and reagents}

Analytical standards of XTR and CBTR were supplied by Sigma-Aldrich (USA). BTR was purchased from Merck (Germany), 4TTR by Fluka (Switzerland), 5TTR by Acros Organics (Belgium); whereas OHBTH was purchased from Alfa Aesar (USA). Stock solutions of individual compounds were prepared in methanol $(\mathrm{MeOH})$ at $1000 \mathrm{mg} \mathrm{L}^{-1}$ and kept at $-18{ }^{\circ} \mathrm{C}$. Working solutions of $10 \mathrm{mg} \mathrm{L}^{-1}$ were prepared when needed and were kept at $-18{ }^{\circ} \mathrm{C}$ for a time period not exceeding three months. Methanol (MeOH, HPLC-MS grade) and acetonitrile (ACN, HPLC grade) were purchased from Merck (Germany) and Fisher (USA), respectively. The solid phase extraction (SPE) cartridges used for samples' clean-up were polymer-based with surface modified styrene divinylbenzene phase (Strata-X, 33u Polymeric Reversed Phase $200 \mathrm{mg} / 6 \mathrm{ml}$ ) and they were supplied by Phenomenex (USA). HPLC grade water was prepared in the laboratory using a MilliQ/MilliRO Millipore system (USA). Ultra-pure $\mathrm{HCl}$ (32\%), used for samples acidification, was purchased from Merck (Germany).

\subsection{Continuous flow systems: set-up and operation}

A small scale continuous flow system was installed and operated in the laboratory (Figure 1), under constant room temperature controlled by central air-conditioning system. The HMBBR system consisted of two aerobic bioreactors $(\mathrm{BC} 1$ and $\mathrm{BC} 2$ ) connected in series, with a working volume of $3 \mathrm{~L}$ each. A settling tank, with a volume of $1 \mathrm{~L}$, followed the $\mathrm{BC} 2$, from which $\mathrm{AS}$ was recirculated to $\mathrm{BC} 1$. Each bioreactor contained both biocarriers (type K3, AnoxKaldnes, at a filling ratio of 30\%) and AS. The AS was collected from a nitrifying municipal STP (Mytilene, Greece), while the biocarriers were taken from a laboratory scale MBBR system that has been operated for six months and on which a mature biofilm was attached [19]. A hydraulic residence time (HRT) of $12.4 \pm 0.6 \mathrm{~h}$ (for each reactor) was applied, providing a substrate organic loading equal to $0.64 \pm 0.39$ $\mathrm{kg} \mathrm{m}^{-3} \mathrm{~d}^{-1}$ for $\mathrm{BC} 1$ and $0.11 \pm 0.09 \mathrm{~kg} \mathrm{~m}^{-3} \mathrm{~d}^{-1}$ for $\mathrm{BC} 2$; whereas sludge residence time (SRT) of AS in the system was kept at $8 \mathrm{~d}$, by daily removing equal amount of sludge from both reactors (Table S1). The HMBBR system was fed with raw wastewater collected from the STP of the University Campus in Mytilene, Greece (Table S2). In all bioreactors, the conservation of aerobic conditions and the adequate mixing of suspended and attached biomass were achieved by providing constant air supply, which ensured that the dissolved oxygen concentration (DO) was always higher than $4 \mathrm{mg} \mathrm{L}^{-1}$.

An acclimatization period of 27 days took place (time almost equal to three times SRT), during which conventional pollutants removal (Chemical Oxygen Demand, $\mathrm{COD} ; \mathrm{NH}_{4}-\mathrm{N}$ ), concentration of suspended and attached biomass and values of $\mathrm{pH}$, temperature $\mathrm{T}$ ) and $\mathrm{DO}$ were frequently examined in order to control the system's stability and efficiency. Afterwards, the target compounds were spiked to the raw wastewater using methanol solutions to obtain a daily stable inflow concentration of approximately $20 \mu \mathrm{g} \mathrm{L}^{-1}$ of each investigated chemical. To evaluate the removal of the target compounds in different bioreactors, 12 samples were taken during one week from different sampling points of the system (Figure 1). 


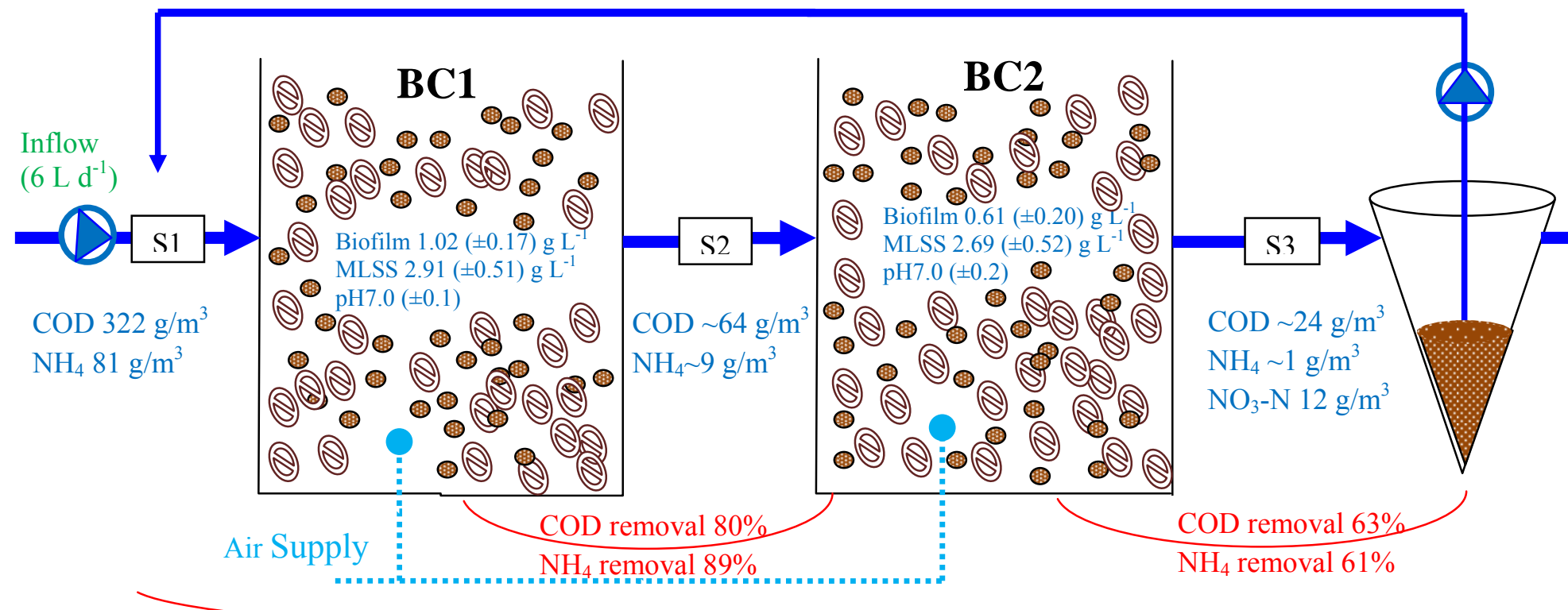

Total Removal

COD $87 \% \& \mathrm{NH}_{4} 98 \%$

Figure 1: Operational characteristics and performance of the HMBBR system (HRT was equal to $12.4 \pm 0.6$ $\mathrm{h}$ for each reactor; sampling points are indicated with an $\mathrm{S}$ ).

\subsection{Batch biodegradation experiments for kinetics calculation}

To determine the contribution of each type of biomass in the removal of target compounds, batch experiments were conducted and biodegradation kinetics was calculated. For this reason, four days after the end of spiking micropollutants to the HMBBR system (time equal to almost eight HRTs), AS and biocarriers were taken from $\mathrm{BC} 1$ and $\mathrm{BC} 2$ and separate batch experiments were conducted for each of the two types of biomass. All experiments were conducted in stoppered glass bottles that were constantly shaken. The working volume in each reactor was $1 \mathrm{~L}$ and aeration was constantly provided through porous ceramic diffusers. The initial wastewater parameters in each flask were similar to those normally found in the bioreactors (Table S3). The investigated compounds were spiked in methanol solutions to obtain an initial concentration of approximately $30 \mu \mathrm{g} \mathrm{L}^{-1}$ for each investigated chemical in the reactors (approximately $0.03 \mathrm{~mL}$ of methanol was added). To quantify the biodegradation of the target chemicals, samples $(50 \mathrm{~mL})$ were collected after $0,1,2.5,5,12$ and 24 hours. Since sorption to organic matter is of minor importance for these compounds [17], the concentrations of target compounds were determined only in the dissolved phase using the analytical method described in Paragraph 2.5.

\subsection{Batch biodegradation experiments for biotransformation products identification}

To identify the biotransformation products of target compounds in the HMBBR system, aerated batch experiments were conducted using biomass from $\mathrm{BC} 1$ where the greatest part of biodegradation was observed during the continuous flow experiment. Mixture of AS and biocarriers from BC1 was transferred to seven different glass bottles at a final volume of $200 \mathrm{~mL}$. Each target compound was spiked in a different bottle at an initial concentration of $10 \mathrm{mg} \mathrm{L}^{-1}$ (approximately $0.2 \mathrm{~mL}$ of methanol were added), while a control flask was also prepared containing biomass and methanol at an amount equal to that added in other reactors. All bottles 
were covered with aluminium foil and constantly agitated on a shaking plate. The total duration of the experiment was $24 \mathrm{~h}$. Three samples $(10 \mathrm{~mL}$ each) were taken from each reactor at 0,6 and $24 \mathrm{~h}$.

\subsection{Analytical methods}

Analysis of COD, $\mathrm{NH}_{4}-\mathrm{N}, \mathrm{NO}_{3}-\mathrm{N}$, Total Suspended Solids (TSS) and Mixed Liquor Suspended Solids (MLSS) were performed according to Standard Methods [20], temperature, DO and $\mathrm{pH}$ were measured using portable instruments. The quantification of the attached biomass was performed by removing the biofilm from biocarriers and measuring the dried weight difference, as described by Falås et al. [21].

For the investigation of target compounds fate, samples were filtered through glass fibre filters (GF-3 Macherey Nagel). Filtrates were collected, acidified to $\mathrm{pH} 3.0 \pm 0.1$ and stored at $4{ }^{\circ} \mathrm{C}$ until analysis. Analysis of target compounds in the dissolved phase was based on previously developed methods [13, 17] and included solid phase extraction (SPE). Chromatographic analysis was performed by a Shimatzu (Japan) LC20-AD prominence liquid chromatographer associated with a SPD-M20A prominence diode array detector and a SIL$20 \mathrm{AC}$ auto sampler. Satisfactory recoveries and precision of the analytical procedure was achieved; where the obtained LODs ranged from $17 \mathrm{ng} \mathrm{L}^{-1}$ (BTR) to $125 \mathrm{ng} \mathrm{L}^{-1}$ (CBTR). Further information for the analytical method and the chromatographic conditions can be found in a recently published paper [17].

For the investigation of transformation products, samples were initially filtered through glass fibre filters (GF-3 Macherey Nagel), $1.5 \mathrm{~mL}$ of each sample was filtered through $0.2 \mu \mathrm{m}$ RC filter and collected. Filtrates were stored at $-18^{\circ} \mathrm{C}$ until analysis. An ultrahigh-performance liquid chromatographic (UHPLC) system (Dionex UltiMate 3000 RSLC, Thermo Fisher Scientific, Germany), coupled with a quadrupole-time-of-flight high-resolution mass spectrometer (UHPLC-QToF-MS) (Maxis Impact QTOF, Bruker, Bremen, Germany) was used for transformation products identification by LC-HRMS/MS.

For TPs' identification, the samples were screened for the exact masses of potential TPs according to a suspect database that was compiled by the online pathway prediction system hosted by EAWAG institute (EAWAG-PPS) without the "relative reasoning mode". Detailed information for the methodology for TPs identification can be found in Supplementary Material (Transformation products identification) and Table S4.

\subsection{Equations}

A brief description of the equations used for the calculation of removal efficiencies, specific removal and applied mass balances is presented below, while detailed information is given in Supplementary Material (Calculations).

The removal efficiency of target compounds in a each bioreactor was calculated as the difference between mass flux entering $\left(\mathrm{m}_{\mathrm{i}}\right)$ and that leaving $\left(\mathrm{m}_{\text {out }}\right)$ each bioreactor (Figure $\mathrm{S} 1$ ), divided by the mass flux of the substance entering the system $\left(\mathrm{M}_{\mathrm{in}}\right)$, as indicated in Eq. (1) [22]:

$$
\text { Removal }(\%)=\frac{m_{i}-m_{\mathrm{gml}}}{\omega_{\mathrm{ln}}} \times 100
$$

Specific removal rate (as $\mu \mathrm{g}$ of micropollutant removed per $\mathrm{g}$ of biomass per day) for each compound was calculated as the difference between mass flux entering $\left(\mathrm{m}_{\mathrm{i}}\right)$ and that leaving $\left(\mathrm{m}_{\text {out }}\right)$ each bioreactor, divided by the total amount of biomass (suspended and attached) in each reactor $\left(X ; \mathrm{g} \mathrm{L}^{-1}\right)$ and the volume of each reactor $(V ; \mathrm{L})$ as described in Eq. (2):

\section{Spectfic Removal Rate $=\frac{m_{+}-m_{\mathrm{eut}}}{X \times V}$}

The biodegradation rate constants $(k)$ were estimated using first order kinetics. Pseudo first-order biodegradation rate coefficient, $k_{\text {bio }}$, normalized to attached or suspended biomass $\left(\mathrm{L} \mathrm{g}^{-1} \mathrm{~d}^{-1}\right)$ was calculated for each biodegradation experiment using the appropriate sorption constant $\left(\mathrm{K}_{\mathrm{d}} ; \mathrm{L} \mathrm{g}^{-1}\right)$ for each compound [17] and Eq. (3) [23]:

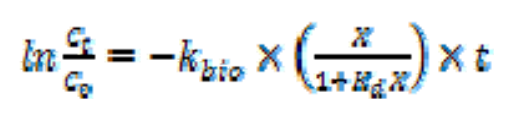


Where $\mathrm{C}_{\mathrm{t}}$ and $\mathrm{C}_{0}$ are the dissolved target compound concentrations in batch experiment at time $\mathrm{t}$ and $\mathrm{t}=0$, respectively $\left(\mu \mathrm{g} \mathrm{L}^{-1}\right)$.

In order to predict the removal of target compounds in each bioreactor and determine the role of each type of biomass on their elimination, Eq. (4) and (5) were used [24] for the existing HMBBR system:

$$
\begin{aligned}
& M_{\text {in } E C 1}=M_{E C 1-o a n}+M_{E C 1-s l_{n}}+M_{\text {sorbed } E C 1}+M_{\text {outEC1 }}
\end{aligned}
$$

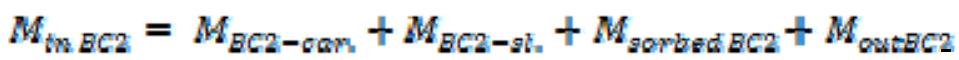

$M_{\text {in }}$ and $M_{\text {out }}$ are the masses of target compounds entering and leaving each reactor respectively $\left(\mu \mathrm{g} \mathrm{d}^{-1}\right)$, $M_{B C 1 \text {-car. }}$ and $M_{B C 1 \text {-sl. }}$ are the masses of target compounds that are biodegraded in BC1, by the attached (carriers) and suspended (AS) biomass respectively $\left(\mu \mathrm{g} \mathrm{d}^{-1}\right), M_{B C 2-c a r}$ and $M_{B C 2-s l}$ are the masses of target compounds that are biodegraded in BC2, by the attached (carriers) and suspended (AS) biomass respectively ( $\mu \mathrm{g} \mathrm{d}^{-1}$ ) and $M_{\text {sorbed }}$ $B C 1$ as well as $M_{\text {sorbed } B C 2}$ is the mass of each target compound removed with excess sludge from each bioreactor $\left(\mu \mathrm{g} \mathrm{d}^{-1}\right)$.

\subsection{Statistical analysis}

In order to compare the removal values and specific removal rates one-way ANOVA was used with the Tukey-Kramer post-test in order to determine significant differences between groups.

\section{Results and Discussion}

\subsection{Operation of continuous flow HMBBR system}

The HMBBR system was stable during the whole experimental period (34 d) and achieved sufficient removal of dissolved COD (87\%) and $\mathrm{NH}_{4} \mathrm{~N}$ (98\%) (Figure 1, Table S5, Figure S1). The major part of conventional pollutants was removed in $\mathrm{BC} 1$, while the use of $\mathrm{BC} 2$ improved further the quality of treated wastewater decreasing the average concentrations of $\mathrm{COD}_{\text {dis }}$ and $\mathrm{NH}_{4}-\mathrm{N}$ to $24 \mathrm{mg} \mathrm{L}^{-1}$ and $1 \mathrm{mg} \mathrm{L}^{-1}$, respectively. As it was expected due to sludge recirculation, the concentrations of activated sludge were almost the same in both bioreactors. On the other hand the increased organic loading into BC1 resulted in a higher concentration of attached biomass $\left(1023 \pm 165 \mathrm{mg} \mathrm{L}^{-1}\right)$ comparing to that observed in BC2 $\left(610 \pm 198 \mathrm{mg} \mathrm{L}^{-1}\right)$.

\subsection{Removal of target compounds in continuous flow HMBBR system}

The HMBBR system exhibited significant decreases of all the target compounds concentrations in wastewater even from the first day of their addition, resulting in average removals ranging between $41 \%$ (4TTR) and $88 \%$ (OHBTH) (Figure 2). The observed decrease of micropollutants concentration was mainly due to biodegradation as it is known that these compounds are not degraded abiotically in STPs and they are poorly sorbed to biomass [17]. Except for 4TTR, all investigated chemicals were removed in BC1, while the second bioreactor $(\mathrm{BC} 2)$ did not statistically significantly improve their removal. The removal of most target compounds in $\mathrm{BC} 1$ where there was a higher COD concentration indicates the role of co-metabolism in the compounds biodegradation. Co-metabolism can be described as the micropollutants decomposition by enzymes that are produced for other primary substation degradation, while micropollutants are not used as carbon and energy source for microbial growth $[25,26]$. Similar observations for the co-metabolic degradation of these target compounds were also described in previous studies $[17,19]$. Concerning 4TTR, it seems that the biomass grown in $\mathrm{BC} 2$ had the ability to biodegrade it, whereas this property was not present in $\mathrm{BC} 1$. So far, in the literature contradictory results have been reported for biodegradation of 4TTR and 5TTR in AS and MBBR systems, indicating the important role of biomass used and the role of specific microorganisms on its removal $[19,27,28]$. 


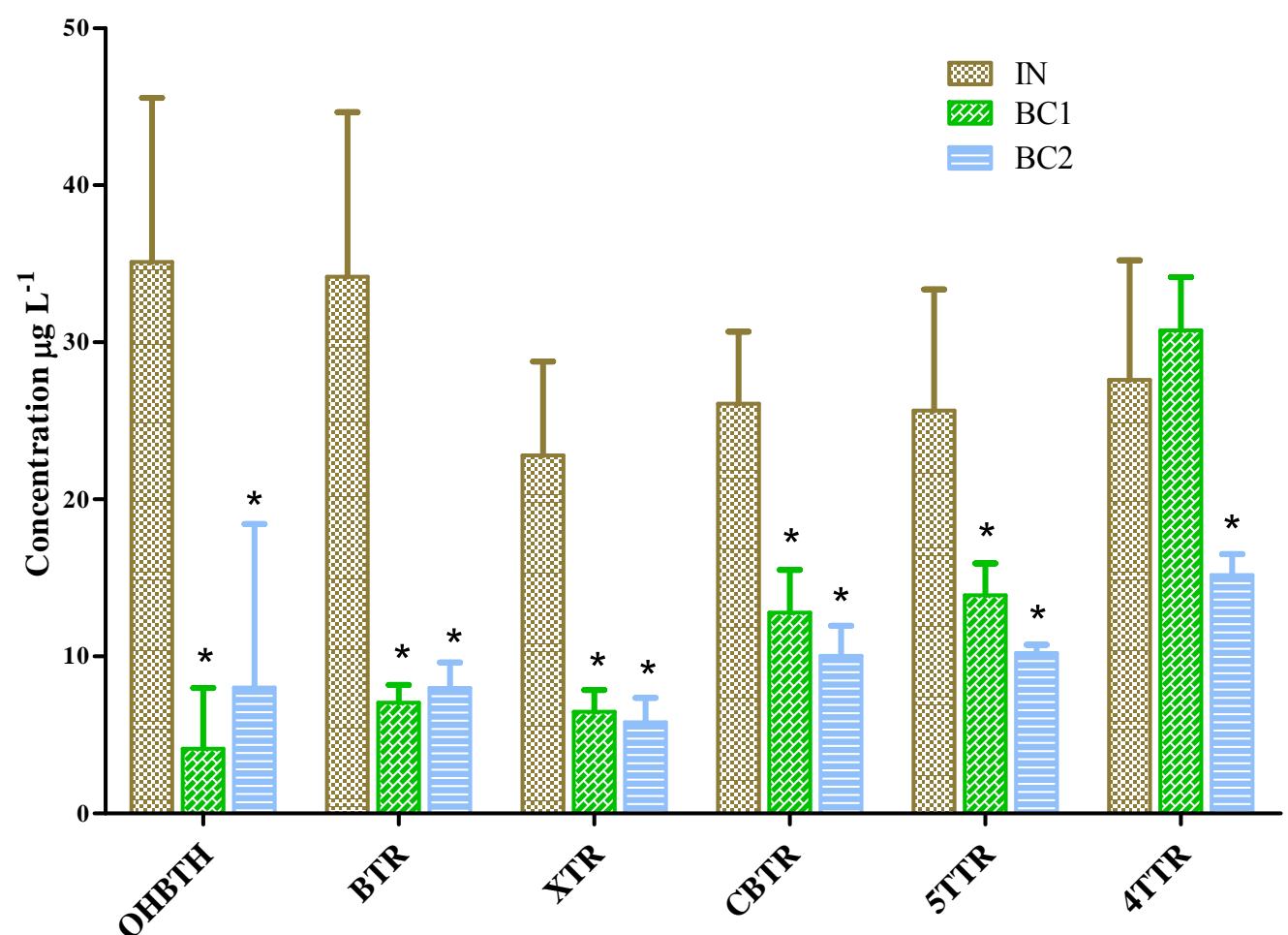

Figure 2: Concentrations (as $\mu \mathrm{g} \mathrm{L}^{-1}$ ) of target compounds in: raw wastewater entering the system (IN), effluent wastewater of the $1^{\text {st }}$ bioreactor $(\mathrm{BC} 1)$ and effluent wastewater of the $2^{\text {nd }}$ bioreactor $(\mathrm{BC} 2)$ of the HMBBR system (t-bars represent 95\% confidence interval; the use of star indicates statistical differences at $95 \%$ confidence level from IN sample).

Comparison of the removal efficiency of target compounds in the HMBBR system with those previously observed in pure MBBR and AS systems [17, 19] showed that the current system achieved similar or statistically higher elimination for 5 out of 6 examined chemicals (Figure 3a). Only 4TTR was removed more efficiently in a pure MBBR system that operated under lower organic loading conditions $\left(0.25 \mathrm{~kg} \mathrm{~m}^{-3} \mathrm{~d}^{-1}\right.$ in the first stage and $0.05 \mathrm{~kg} \mathrm{~m}^{-3} \mathrm{~d}^{-1}$ in the second stage) and double HRT. It is worth mentioned that when the performance of the HMBBR system is compared with that of a pure MBBR system operated under similar organic loading and HRT conditions (MBBR-high, Figure 3a), a statistically significant increase of removal is observed for 5 out of 6 target compounds, indicating the advantage of the hybrid system on micropollutants removal comparing to a pure MBBR system operated under the same conditions. Finally, the hybrid system achieved statistically higher removal efficiencies for XTR and 5TTR and similar removal for the other compounds comparing to an AS system operated at the double HRT and the same concentration of suspended biomass (Figure 3a). In a previous study, Di Trapani et al. [29] reported that HMBBR systems can achieve similar performance in terms of organic and nitrogen removal as a traditional AS system operating at lower hydraulic loading, however, to the best of our knowledge, this it is the first time that this is described for micropollutants removal. 


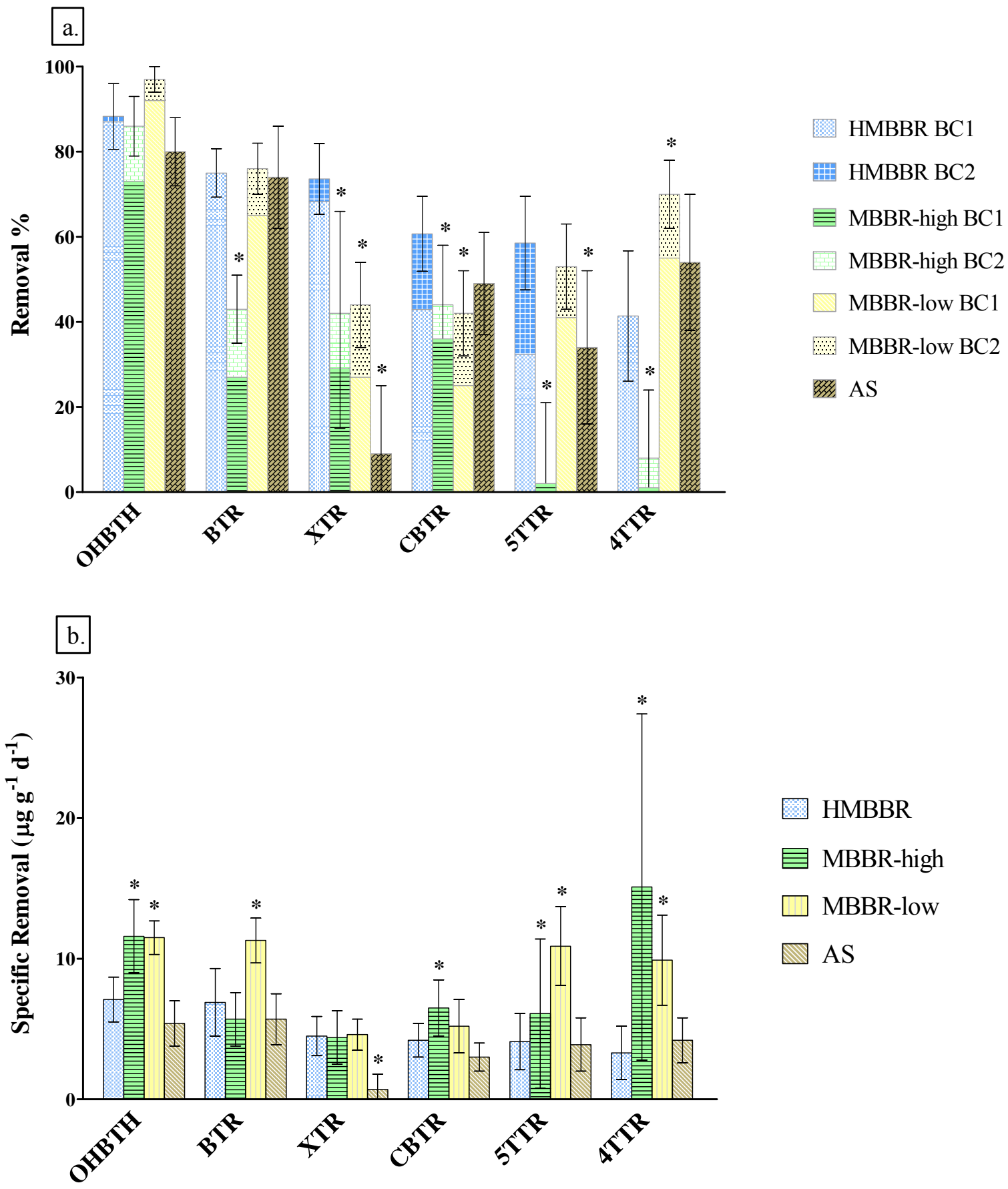

Figure 3: Comparison of the removal efficiency of target compounds (a) and the specific removal of micropollutants (b) inthe HMBBR system used in this study with other MBBR and AS systems previously used by Mazioti et al., (2015b). MBBR-high system consisted of two bioreactors in series receiving an organic loading of $0.60 \mathrm{~kg} \mathrm{~m}^{-3} \mathrm{~d}^{-1}$ and $0.17 \mathrm{~kg} \mathrm{~m}^{-3} \mathrm{~d}^{-1}$, respectively; MBBR-low system consisted of two bioreactors in series receiving an organic loading of $0.25 \mathrm{~kg} \mathrm{~m}^{-3} \mathrm{~d}^{-1}$ and $0.05 \mathrm{~kg} \mathrm{~m}^{-3} \mathrm{~d}^{-1}$, respectively and AS operated on an organic loading of $0.25 \mathrm{~kg} \mathrm{~m}^{-3} \mathrm{~d}^{-1}$ (t-bars represent $95 \%$ confidence interval; the use of star indicates statistical differences at $95 \%$ confidence level from HMBBR system).

Mazioti et al., J. Hazard Materials, 2016 Post Print -

Publishers version available at: www.sciencedirect.com/science/journal/03043894 
Having in mind that the concentration of biomass in different systems was different, following the decreasing order: HMBBR > AS > MBBR (Table S3), the specific removal expressed as $\mu \mathrm{g}$ of micropollutant per $\mathrm{g}$ of biomass per $\mathrm{d}$ was calculated for each compound and compared to values reported by Mazioti et al. [19] for pure MBBR and AS systems (Figure 3b). No statistical differences (except for XTR) were observed on the ability of HMBBR biomass and AS biomass to remove target compounds. On the other hand, biomass developed in pure MBBR systems showed statistically significant higher specific removal for most target compounds (Figure 3b), indicating the presence of more efficient bacteria for biodegradation of micropollutants in biofilm developed in a pure MBBR system compared to the HMBBR system. So far, no comparison has been done on the diversity of microorganisms grown on biofilm of hybrid and pure MBBR systems and on their potential to remove micropollutants.

\subsection{Biodegradation kinetics of attached and suspended biomass of HMBBR system}

Batch experiments were conducted to determine the first order rate constant, $\mathrm{k}$, and normalised rate constant, $\mathrm{k}_{\mathrm{bio}}$, for each types of biomass (AS, attached biomass on biocarriers) from $\mathrm{BC} 1$ and $\mathrm{BC} 2$. The highest biodegradation constants were calculated for OHBTH, whereas 4TTR and 5TTR exhibited slow degradation (Table S6).

Different normalised biodegradation constants were calculated for the two types of biomass contained in the same bioreactor, indicating the significant role of both types of biomass on the removal of this group of micropollutants in a HMBBR system (Figure 4). Specifically in BC1, OHBTH and BTR were biodegraded more rapidly by AS, whereas the opposite was observed for CBTR. Additionally in BC2, higher $\mathrm{k}_{\text {bio }}$ were calculated for OHBTH, BTR, XTR and CBTR by attached biomass.

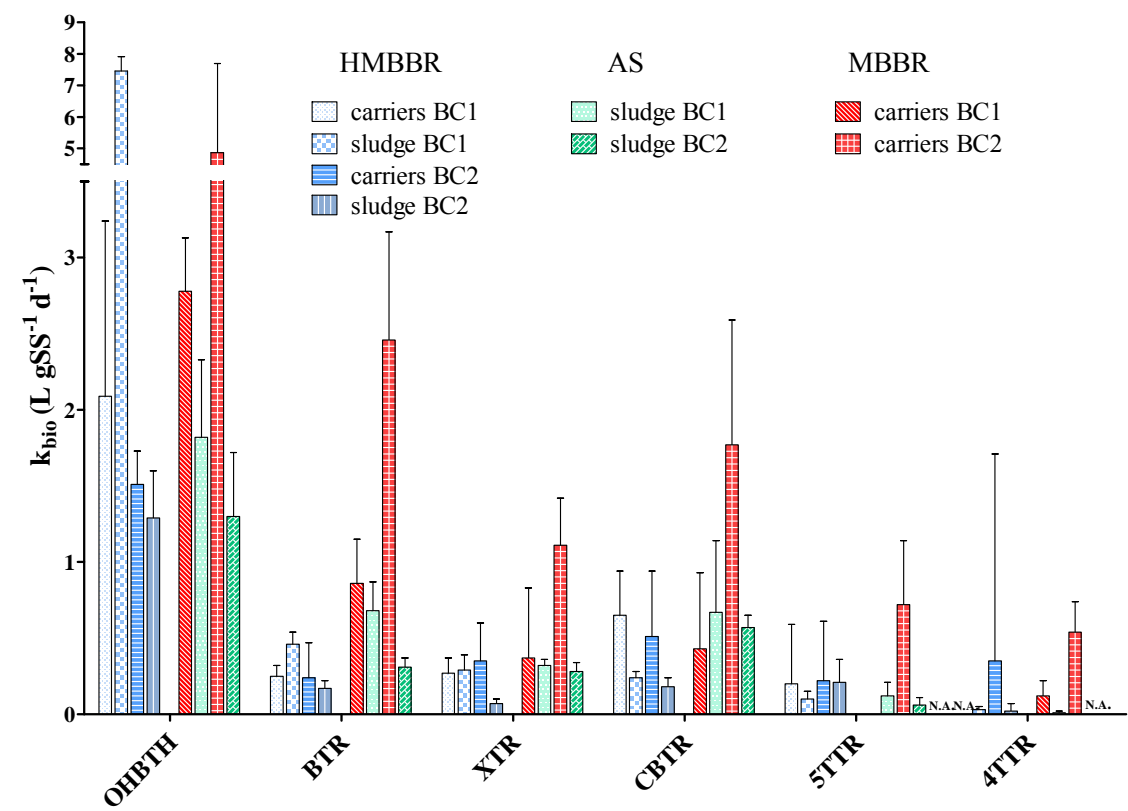

Figure 4: Biodegradation constants $\left(\mathrm{k}_{\mathrm{bio}}\right.$, asL $\left.\mathrm{g}_{\mathrm{SS}}{ }^{-1} \mathrm{~d}^{-1}\right)$ for the HMBBR system calculated in batch experiments with activated sludge and attached biomass from $\mathrm{BC} 1$ and $\mathrm{BC} 2$, compared with constants from a pure MBBR and a conventional AS system (Mazioti et al., 2015b).

Comparing the biodegradation kinetics obtained for the same type of biomass in different bioreactors of HMBBR system, in experiments with AS lower $\mathrm{k}_{\text {bio }}$ 's were calculated for OHBTH, BTR, XTR and CBTR in BC2 (Figure 4, Table S6). As mentioned in paragraph 2.3 and Table S3, batch experiments with biomass from $\mathrm{BC} 2$ were conducted under lower organic substrate concentration comparing to those with biomass from $\mathrm{BC} 1$ 
in order to simulate the conditions in the continuous-flow system and be able to afterwards use the calculated constants for model development. Having in mind that the biodegradation of the target compounds by AS is cometabolic [17] and AS recirculates in the system, the lower $\mathrm{k}_{\mathrm{bio}}$ values observed in $\mathrm{BC} 2$ are possibly due to the experimental conditions (lower COD) applied in these batch experiments. Concerning the attached biomass, similar biodegradation constants were calculated for OHBTH, BTR, XTR, CBTR and 5TTR in both bioreactors (Figure 4). As co-metabolic biodegradation of these compounds has also been reported for the attached biomass [19], it is likely that the higher COD concentration that was used in the experiments with biomass from BC1 increased to some extent the observed biodegradation rates. Based on the above, it can be assumed that if similar concentrations of COD had been used in both batch experiments, $\mathrm{k}_{\text {bio }}$ in $\mathrm{BC} 1$ would be lower compared to those in $\mathrm{BC} 2$.

Comparison of the biodegradation constants obtained in this study with $\mathrm{k}_{\mathrm{bio}}$ values calculated in a previous study [19] using attached biomass from a pure MBBR system and AS from a conventional AS system (Figure 4) shows that except for OHBTH among all bioreactors higher biodegradation constants were obtained in the $2^{\text {nd }}$ bioreactor of the pure MBBR system. This observation indicates that in the biofilm of a pure MBBR system there is the potential to develop more specialised microorganisms for biodegradation of micropollutants.

\subsection{Contribution of different types of biomass to target compounds removal}

The removal of target compounds in the HMBBR system was predicted using batch biodegradation kinetics and Equations 4 and 5. Despite the underestimation of removal efficiencies that was observed for some of the target compounds especially in the first reactor $(\mathrm{BC} 1)$, the applied model described sufficiently the order of removal of studied micropollutants in HMBBR system (Figure 5). Concerning the contribution of different types of biomass to the target compounds removal, it seems that biodegradation by AS occurring in $\mathrm{BC} 1$ is the major mechanism for OHBTH, BTR, XTR and CBTR.

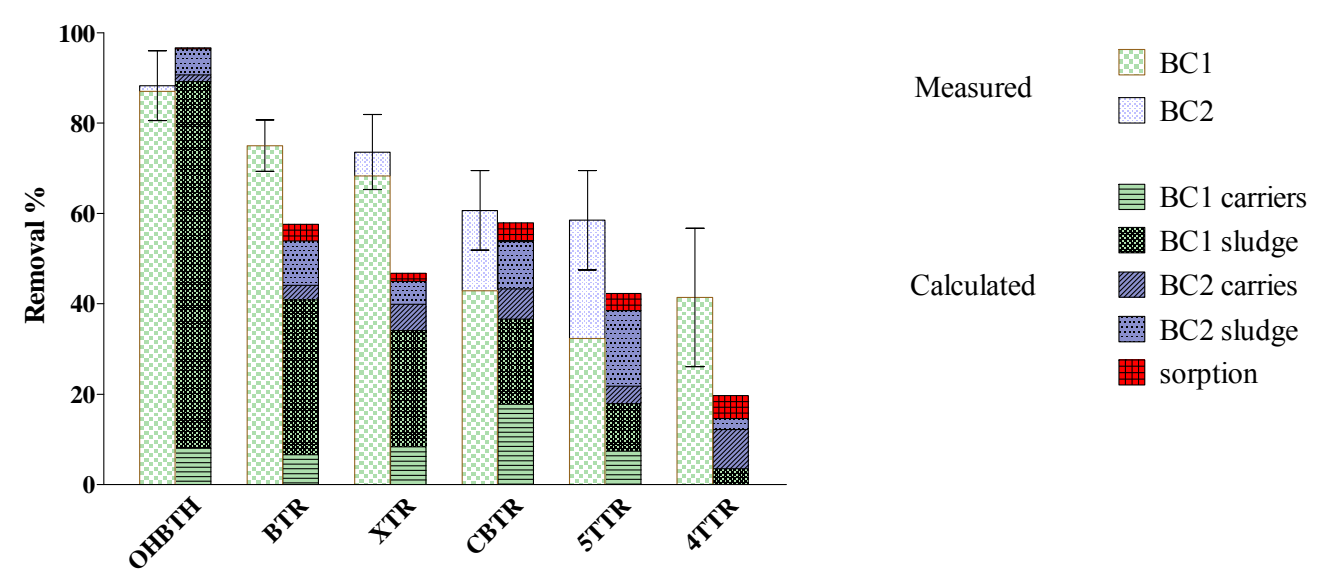

Figure 5: Measured and predicted removal of target compounds in HMBBR system. The contribution of different types of biomass (carriers and sludge) and different mechanisms on their removal is also shown (for predicted removal, the biodegradation with $\mathrm{BC} 1$ and $\mathrm{BC} 2$ carriers and sludge as well as the sorption on sludge were determined).

Both biocarriers and $\mathrm{AS}$ of $\mathrm{BC} 1$ and $\mathrm{BC} 2$ contribute significantly on biodegradation of 5TTR, whereas the attached biomass on biocarriers of $\mathrm{BC} 2$ has critical role for 4TTR biodegradation. As it was expected due to the hydrophilicity of these compounds, the role of sorption in their removal is of minor importance. The aforementioned results indicate that the most easily biodegradable micropollutants can be mainly removed in the first bioreactor of a HMBBR system due to the activity of suspended biomass, while attached biomass in the 
second bioreactor seems to have an important role on the elimination of hardly biodegradable polar micropollutants.

\subsection{Biotransformation Products}

Twenty two transformation products were tentatively identified in total with mass accuracy $\pm 5 \mathrm{ppm}$. The $\mathrm{m} / \mathrm{z}$ range of the candidate TPs ranged from 132.0567 (TP14) to 245.9536 (TP22). For the majority of the candidates, retention times showed the formation of more polar TPs than the parent compounds. A distinctive time trend (absent in the blank, increasing peak over incubation time) was observed for all candidate TPs. All information about TPs is summarized in Table 1. As identification confidence in HR-MS is sometimes difficult to communicate in an accurate way [30], in the present work we used the levels of identification confidence proposed by Schymanski et al. [31]. BTR presented the higher degree of biotransformation compared to the other BTRs [18]. Five candidate TPs were found in positive mode (TP1-TP5) and 4 more (TP6-TP9) in negative mode. Hydroxylation was the dominant reaction mechanism followed by oxidation and methylation. Previously reported TPs for BTR $[16,18]$ were among the tentatively identified TPs (TP1-TP7, TP9). In total, five TPs (TP3-TP7) were identified by library spectrum match and the records from the online mass spectra database, MassBank, were reported. Two TPs (TP2 and TP8) were tentatively identified and probable structures were proposed. TP1 (1-OH BTR) was confirmed by a reference standard and for TP9 an unequivocal molecular formula was reported (identification level 1 and 4, respectively; [31]). Biotransformation of 4TTR showed 5 candidate TPs (TP10-TP14). Hydroxylation and oxidation were found to be the most probable reaction mechanisms for the formation of the TPs. In positive mode only TP10 $\left(\mathrm{C}_{7} \mathrm{H}_{5} \mathrm{~N}_{3} \mathrm{O}_{2}\right)$ was identified with a tentative structure that is illustrated in Table 1. In negative mode, 4 more TPs were identified. Hydroxylation of the benzene ring was identified for TP14 whereas monohydroxylation of the methyl group were identified for TP13. Both hydroxylation and oxidation reactions were involved in formation of TP11-TP12. For TP12 the probable structure of 4-COOH BTR was proposed by a library spectrum match (Id. level 2a). 5TTR degradation revealed the formation of 3 candidate TPs (TP15-TP17). TP15 was identified to be 5-COOH BTR by a library spectrum match (Id. level 2a). The tentative structure of TP16 $\left(\mathrm{C}_{7} \mathrm{H}_{7} \mathrm{~N}_{3} \mathrm{O}\right)$ corresponds to monohydroxylation, whereas TP17 $\left(\mathrm{C}_{7} \mathrm{H}_{7} \mathrm{~N}_{3} \mathrm{O}_{2}\right)$ corresponds to a dihydroxylation of the benzene ring (ident. level 3$)$. To our knowledge, biodegradation products of XTR has not been studied before, and this is the first report of its biotransformation products. Two candidate TPs (TP18-TP19) were found for XTR and tentative structures were proposed (Id. level 3). TP18 $\left(\mathrm{C}_{8} \mathrm{H}_{7} \mathrm{~N}_{3} \mathrm{O}_{2}\right)$ corresponds to the formation of carboxylic acid XTR, while TP19 $\left(\mathrm{C}_{8} \mathrm{H}_{9} \mathrm{~N}_{3} \mathrm{O}\right)$ indicates either the monohydroxylation of a methyl group or monohydroxylation of the benzene ring of XTR, which was detected in both positive and negative ionization mode. CBTR did not show any potential TP according to the screened database either in positive or negative ionization mode. Finally, OHBTH has also not been studied before, and this is the first report of its biotransformation products. Three candidate TPs (TP20-TP22) were identified and tentative structures were proposed for OHBTH (Id. level 3). TP20 of OHBTH $\left(\mathrm{C}_{8} \mathrm{H}_{7} \mathrm{NO}_{2} \mathrm{~S}\right)$ indicates methoxylation of the benzene ring, whereas the candidate TPs in negative mode TP21 $\left(\mathrm{C}_{7} \mathrm{H}_{5} \mathrm{NO}_{2} \mathrm{~S}\right)$ and TP22 $\left(\mathrm{C}_{7} \mathrm{H}_{5} \mathrm{NO}_{5} \mathrm{~S}_{2}\right)$ correspond to a hydroxylation of the benzene ring followed by the formation of a sulfonic ester in one of the two hydroxyl groups, respectively. 
Table 1. Description of candidate TPs observed in batch biodegradation experiments with biomass from HMBBR system

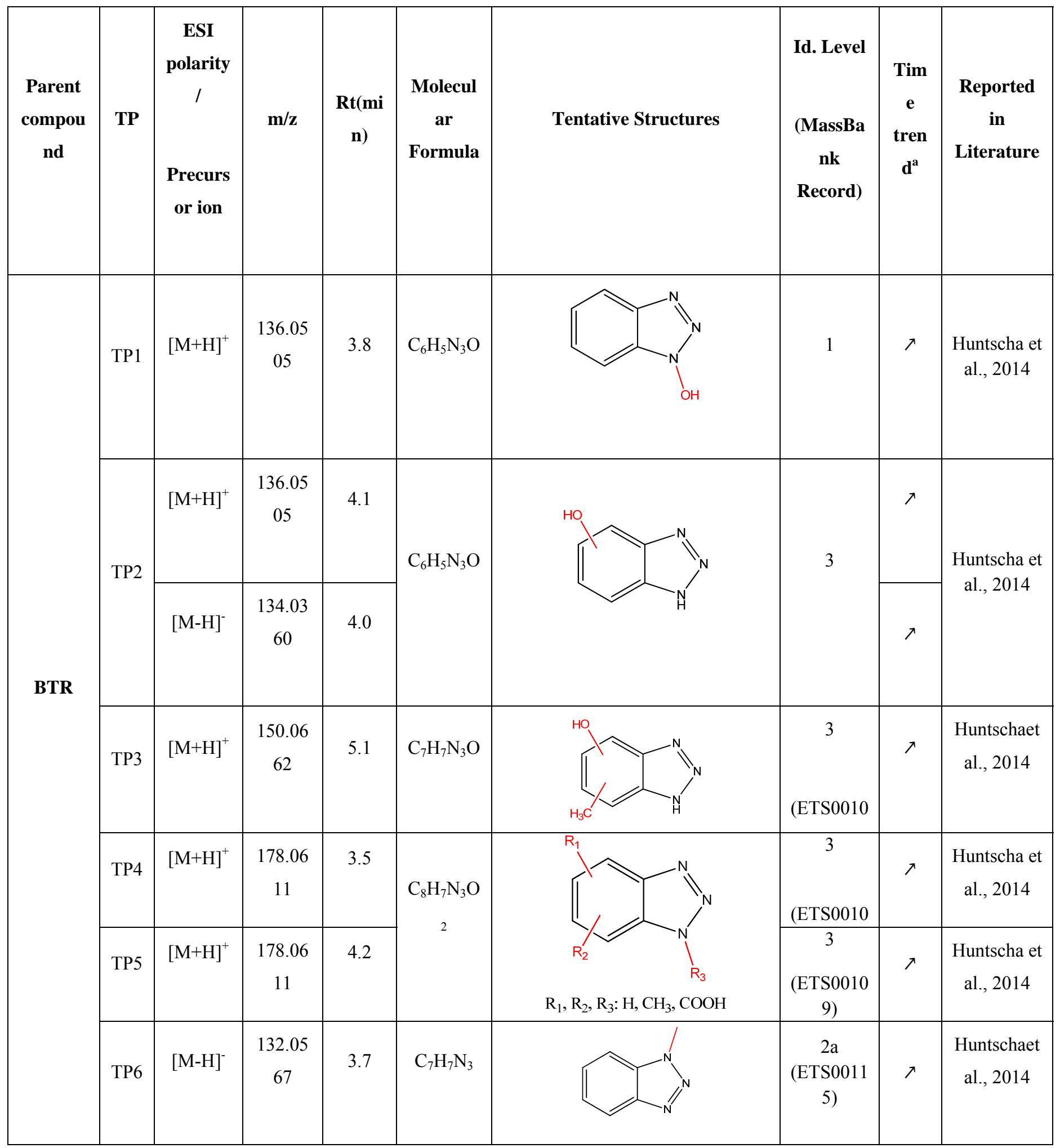




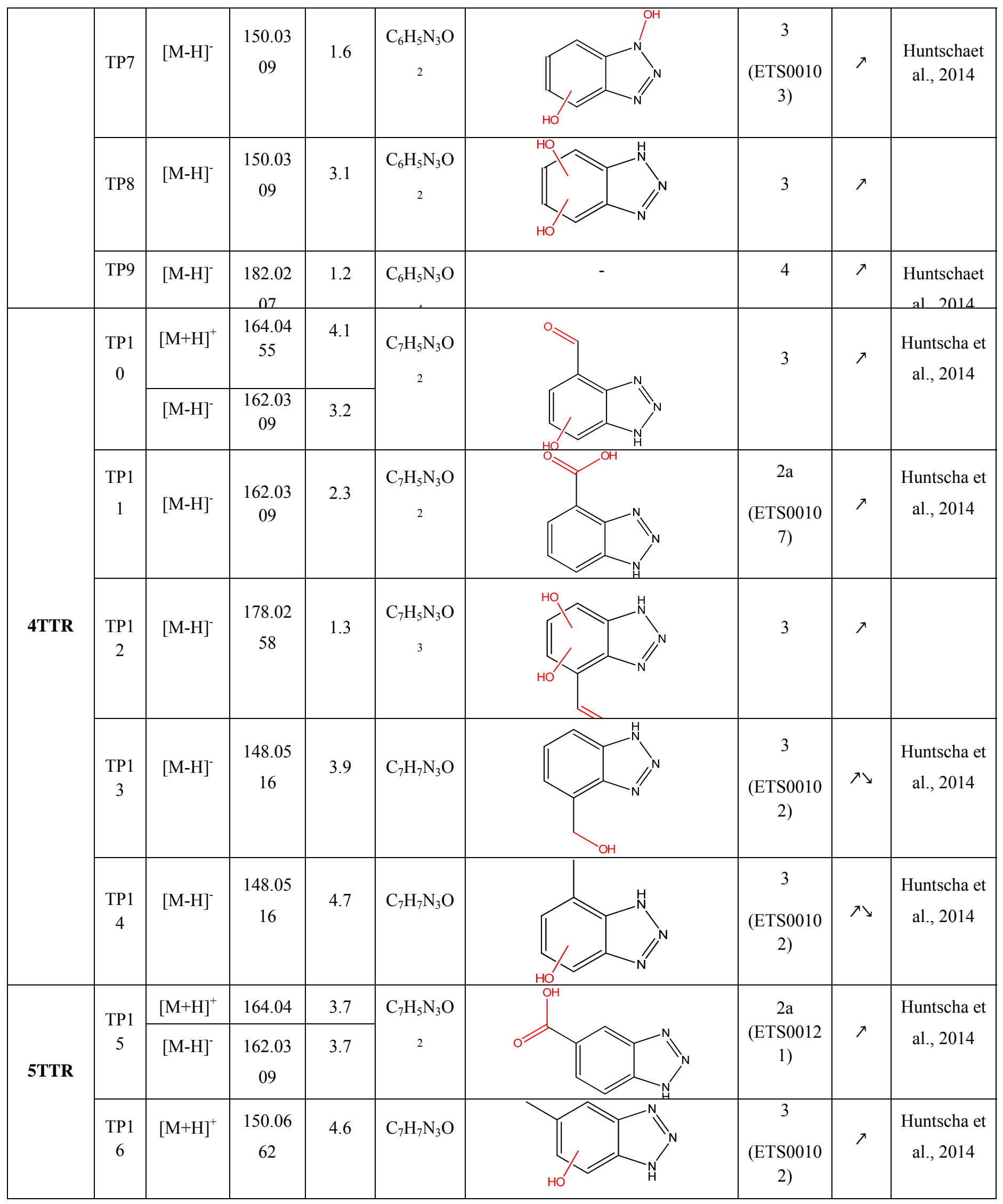




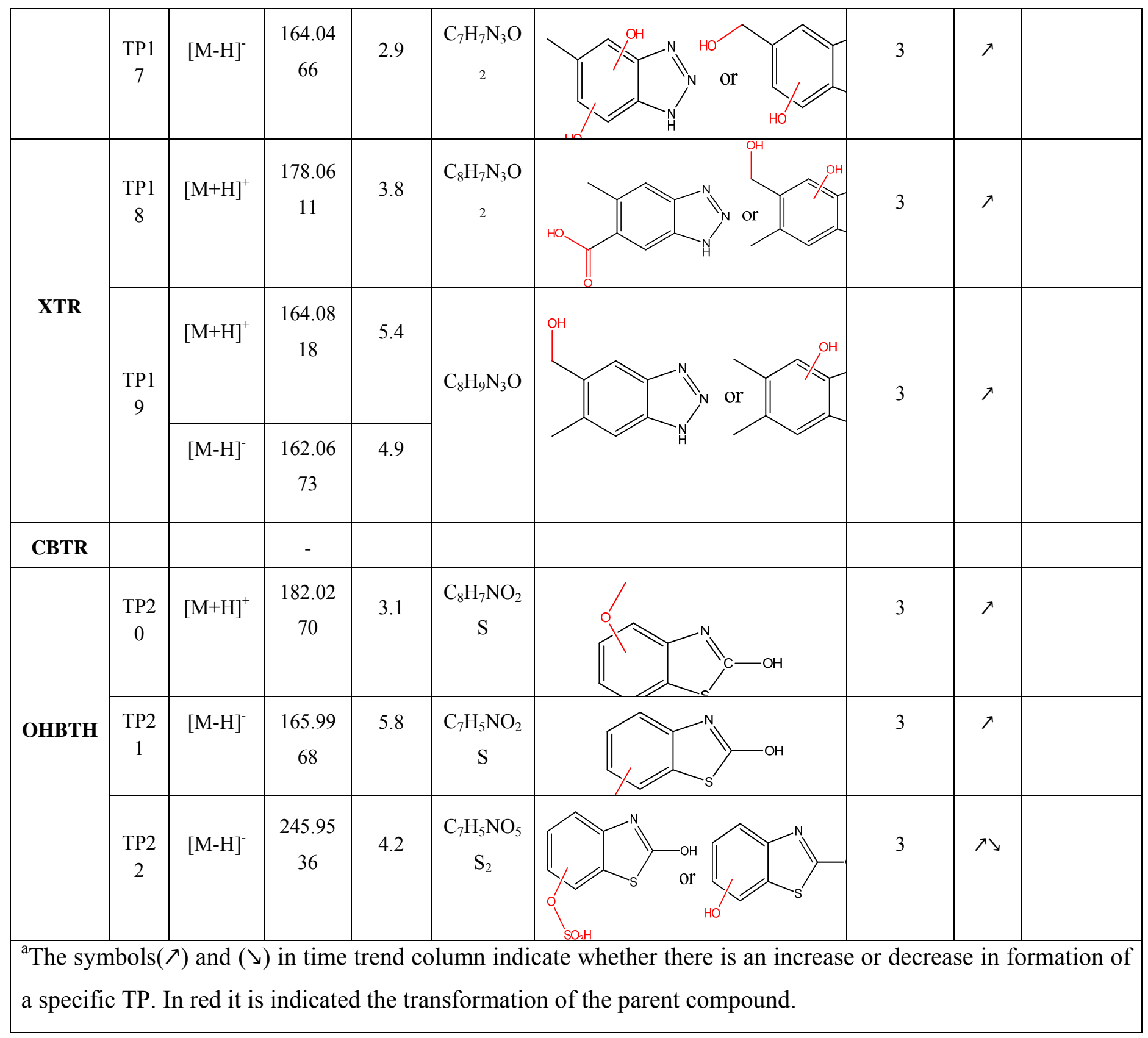

\section{Conclusions}

HMBBR partially removed all target micropollutants. Co-metabolic biodegradation was the major degradation mechanism. AS and biocarriers contributed to the biodegradation to different extent. HMBBR performance was similar to a low loaded pure MBBR system and more efficient than AS and MBBR systems operating under the same HRT and organic loading conditions. HMBBR biomass and biomass from traditional AS systems showed no differences on the specific removal rate of target compounds; whereas biomass grown in pure MBBR systems was more efficient. BTR presented more biotransformation products among all target compounds.

\section{Acknowledgments}

This research has been co-financed by the European Union and Greek national funds: THALES (WATERMICROPOL, http://www2.env.aegean.gr/WaterMicropol/). Biocarriers used in the experiments 
were kindly provided by AnoxKaldnes, Lund, Sweden. A. Stasinakis would like to thank DTU (Department of Environmental Engineering) for hosting him in the period that this article was written. The authors would like to thank Mrs Agapi Taka and Mrs Evdoxia Chroni for their valuable help during the experiments.

\section{References}

[1] Randall, C.W., Sen, D., 1996. Full-scale evaluation of an integrated fixed-film activated sludge (IFAS) process for enhanced nitrogen removal. Water Science and Technology 33, 155-162

[2] Di Trapani, D., Christensson, M., Torregrossa, M., Viviani, G., Ødegaard, H., 2013. Performance of a hybrid activated sludge/biofilm process for wastewater treatment in a cold climate region: Influence of operating conditions. Biochemical Engineering Journal 77, 214-219.

[3] Mannina, G., Viviani, G., 2009. Hybrid moving bed biofilm reactors: An effective solution for upgrading a large wastewater treatment plant. Water Science and Technology 60, 1103-1116.

[4] Di Trapani, D., Christensson, M., Ødegaard, H.C., 2011. Hybrid activated sludge/biofilm process for the treatment of municipal wastewater in a cold climate region: A case study. Water Science Technology 63, 1121-1129.

[5] Falås, P., Longrée, P., La Cour Jansen, J., Siegrist, H., Hollender, J., Joss, A., 2013. Micropollutant removal by attached and suspended growth in a hybrid biofilm-activated sludge process. Water Research 47, 44984506.

[6] Escolà Casas, M., Chhetri, R.K., Ooi, G., Hansen, K.M.S., Litty, K., Christensson, M., Kragelund, C., Andersen, H.R., Bester, K., 2015. Biodegradation of pharmaceuticals in hospital wastewater by a hybrid biofilm and activated sludge system (Hybas). Science of the Total Environment 530-531, 383-392.

[7] Sfaelou, S., Papadimitriou, C.A., Manariotis, I.D., Rouse, J.D., Vakros, J., Karapanagioti, H.K. 2015 Treatment of low-strength municipal wastewater containing phenanthrene using activated sludge and biofilm process. Desalination and Water Treatment, (article in press; doi:10.1080/19443994.2015.1048735).

[8] Farré, M., Pérez, S., Kantiani, L., Barceló, D., 2008. Fate and toxicity of emerging pollutants, their metabolites and transformation products in the aquatic environment, TrAC Trends in Analytical Chemistry 27, 991-1007.

[9] Reemtsma, T., Miehe, U., Duennbier, U., Jekel, M., 2010. Polar pollutants in municipal wastewater and the water cycle: Occurrence and removal of benzotriazoles. Water Research 44, 596-604.

[10] Herrero, P., Borrull, F., Pocurull, E., Marcé, R.M. 2014. An overview of analytical methods and occurrence of benzotriazoles, benzothiazoles and benzenesulfonamides in the environment. TrAC - Trends in Analytical Chemistry 62, 46-55.

[11] Reemtsma, T., Weiss, S., Mueller, J., Petrovic, M., González, S., Barcelo, D., Ventura, F., Knepper, T.P., 2006. Polar pollutants entry into the water cycle by municipal wastewater: A European perspective. Environmental Science and Technology 40, 5451-5458.

[12] Nödler, K., Voutsa, D., Licha, T., 2014. Polar organic micropollutants in the coastal environment of different marine systems. Marine Pollution Bulletin 85, 50-59.

[13] Asimakopoulos, A.G., Ajibola, A., Kannan, K., and Thomaidis, N.S., 2013. Occurrence and removal efficiencies of benzotriazoles and benzothiazoles in a wastewater treatment plant in Greece. Science of the Total Environment 452-453, 163-171.

[14] Stasinakis, A.S., Thomaidis, N.S., Arvaniti, O.S., Asimakopoulos, A.G., Samaras, V.G., Ajibola, A., Mamais, D., Lekkas, T.D., 2013. Contribution of primary and secondary treatment on the removal of benzothiazoles, benzotriazoles, endocrine disruptors, pharmaceuticals and perfluorinated compounds in a sewage treatment plant. Science of the Total Environment 463-464, 1067-1075.

[15] Molins-Delgado, D., Díaz-Cruz, S. M., Barceló, D., 2015. Removal of polar UV stabilizers in biological wastewater treatments and ecotoxicological implications. Chemosphere 119, S51-S57.

[16] Liu, Y.-S., Ying, G.-G., Shareef, A., Kookana, R.S., 2011. Biodegradation of three selected benzotriazoles under aerobic and anaerobic conditions. Water Research 45, 5005-5014. 
[17] Mazioti, A.A., Stasinakis, A.S., Gatidou, G., Thomaidis, N.S., Andersen, H.R., 2015. Sorption and biodegradation of selected benzotriazoles and hydroxybenzothiazole in activated sludge and estimation of their fate during wastewater treatment Chemosphere 131, 117-123.

[18] Huntscha, S., Hofstetter, T.B., Schymanski, E.L., Spahr, S., Hollender, J. 2014. Biotransformation of benzotriazoles: Insights from transformation product identification and compound-specific isotope analysis. Environmental Science and Technology 48, 4435-4443.

[19] Mazioti, A.A., Stasinakis, A.S., Pantazi, Y., Andersen, H.R., 2015. Biodegradation of benzotriazoles and hydroxy-benzothiazole in wastewater by activated sludge and moving bed biofilm reactor systems, Bioresource Technology 192, 627-635.

[20] APHA, 1998. Standard methods: for the examination of water and wastewater, American Public Health Association, $20^{\text {th }}$ edition.

[21] Falås, P., Baillon-Dhumez, A., Andersen, H.R., Ledin, A., La Cour Jansen, J., 2012. Suspended biofilm carrier and activated sludge removal of acidic pharmaceuticals. Water Research 46, 1167-1175.

[22] Carballa, M., Omil, F., Ternes, T., Lema, J.M., 2007. Fate of pharmaceutical and personal care products (PPCPs) during anaerobic digestion of sewage sludge, Water Research, 41, 2139-2150.

[23] Ziels, R.M., Lust, M.J., Gough, H.L., Strand, S.E., Stensel, H.D., 2014. Influence of bioselector processes on $17 \alpha$-ethinylestradiol biodegradation in activated sludge wastewater treatment systems. Environmental Science and Technology 48, 6160-6167.

[24] Tchobanoglous G., Burton F.L., Stensel D.H., 2002. Wastewater Engineering: Treatment Disposal Reuse. $4^{\text {th }}$ ed.: McGraw Hill, Boston, USA.

[25] Daughton, C.G., Ternes, T.A., 1999. Pharmaceuticals and personal care products in the environment: Agents of subtle change? Environmental Health Perspectives, 107, 907-938.

[26] Vader JS., Van Ginkel CG., Sperling FMGM., De Jong J., De Boer W., De Graaf JS., 2000. Degradation of ethinyl estradiol by nitrifying activated sludge. Chemosphere 41, 1239-1243.

[27] Weiss, S., Jakobs, J., Reemtsma, T., 2006. Discharge of three benzotriazole corrosion inhibitors with municipal wastewater and improvements by membrane bioreactor treatment and ozonation, Environmental Science and Technology 40, 7193-7199.

[28] Herzog, B., Yuan, H., Lemmer, H., Horn, H., Müller, E., 2014. Effect of acclimation and nutrient supply on 5-tolyltriazole biodegradation with activated sludge communities. Bioresource Technology 163, 381-385.

[29] Di Trapani, D., Mannina, G., Torregrossa, M., Viviani, G., 2010. Comparison between hybrid moving bed biofilm reactor and activated sludge system: A pilot plant experiment. Water Science and Technology 61, 891-902.

[30] Bletsou, A.A., Jeon, J., Hollender, J, Archontaki, E., Thomaidis, N.S., 2015. Targeted and non-targeted liquid chromatography-mass spectrometric workflows for identification of transformation products of emerging pollutants in the aquatic environment, TrAC Trends in Analytical Chemistry 66, 32-44.

[31] Schymanski, E.L., Jeon, J., Gulde, R., Fenner, K., Ruff, M., Singer, H.P., Hollender, J. 2014. Identifying small molecules via high resolution mass spectrometry: communicating confidence. Environmental Science \& Technology 48, 2097-2098. 


\section{Supplementary Information}

Hybrid Moving Bed Biofilm Reactor for the biodegradation of benzotriazoles and hydroxybenzothiazole in wastewater

Aikaterini A. Mazioti ${ }^{\mathrm{a}}$, Athanasios S. Stasinakis ${ }^{\mathrm{a}, \mathrm{b}^{*}}$, Aikaterini K. Psoma ${ }^{\mathrm{c}}$, Nikolaos S. Thomaidis $^{\mathrm{c}}$, Henrik R. Andersen ${ }^{\mathrm{b}}$

${ }^{\mathrm{a}}$ Department of Environment, University of the Aegean, 81100 Mytilene, Greece

${ }^{b}$ Departmentof Environmental Engineering, Technical University of Denmark, Miljøvej, B 113, 2800 Kgs. Lyngby, Denmark

${ }^{\mathrm{c}}$ Department of Chemistry, National and Kapodistrian University of Athens, Panepistimioupolis Zografou, 15771 Athens, Greece
A. Analysis of Equations used
B. Analytical method used for transformation products identification
C. Supplementary Tables and Figures
D. References 


\section{A. Calculations}

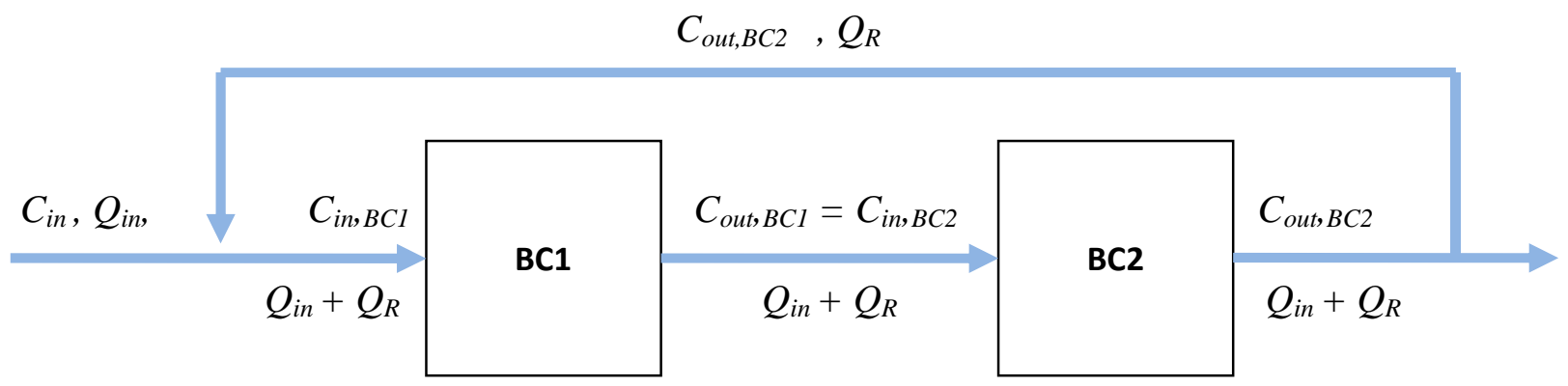

Figure S1: Schematic description of HMBBR system and symbols used in equations.

Equation 1 that is described in the manuscript can be further analyzed as follows:

$$
\operatorname{Removal}(\%)=\frac{m_{i}-m_{\text {out }}}{M_{i}} \times 100=\left(\frac{C_{\text {in }, B C i}-C_{\text {out }, B C i}}{C_{\text {in }}}\right) \times\left(\frac{Q_{\text {in }}+Q_{R}}{Q_{\text {in }}}\right) \times 100
$$

Where $\mathrm{m}_{\mathrm{i}}$ and $\mathrm{m}_{\text {out }}$ indicate the mass flux entering and leaving each bioreactor respectively, and $\mathrm{M}_{\mathrm{in}}$ the mass flux of the substance entering the system. $C_{i n}$ is the concentration of each target compound entering the system $\left(\mu \mathrm{g} \mathrm{L}^{-1}\right)$ and $Q_{\text {in }}$ is the amount of wastewater entering the system daily $\left(\mathrm{m}^{3} \mathrm{~d}^{-1}\right) . C_{i n, B C i}$ is the actual concentration entering in each reactor (after recirculation) and $C_{\text {out }, B C i}$ is the concentration at the outlet of each reactor $\left(\mu \mathrm{g} \mathrm{L}^{-1}\right) . Q_{R}$ is the amount of wastewater that is recirculated from the exit of $\mathrm{BC} 2$ to the inflow stream of the system on a daily basis $\left(\mathrm{m}^{3} \mathrm{~d}^{-1}\right)$.

Equation 2 that is described in the manuscript can also be further analyzed as follows:

Specific Removal Rate $=\frac{m_{i}-m_{\text {out }}}{X \times V}=\left(\frac{C_{\text {in, BCi }}\left(Q_{\text {in }}+Q_{R}\right)-C_{\text {out }, B C i}\left(Q_{\text {in }}+Q_{R}\right)}{X \times V}\right)$ 
The equations 4 and $\mathbf{5}$, used in the manuscript to predict the removal of target compounds in each bioreactor and determine the role of each type of biomass on their elimination, can be further analyzed as follows:

\section{For $\mathrm{BC} 1$ and equation 4}

$$
\begin{aligned}
& M_{\text {in } B C 1}=M_{B C 1-\text { car. }}+M_{B C 1-s l .}+M_{\text {sorbed } B C 1}+M_{\text {out } B C 1} \quad \text { or } \\
& C_{\text {in }} Q_{\text {in }}+C_{\text {out }, B C 2} Q_{R}= \\
& k_{\text {bio-car } 1} X_{\text {car } 1} V C_{o u t, B C 1}+k_{\text {bio-sl1 } 1} X_{\text {sl1 } 1} V C_{\text {out }, B C 1}+\frac{\left(X_{s l 1} V K_{d} C_{o u t, B C 1}\right)}{S R T}+\left(Q_{\text {in }}+Q_{R}\right) C_{o u t, B C 1}
\end{aligned}
$$

\section{$\underline{\text { For } \mathrm{BC} 2 \text { and equation } 5}$}

$$
\begin{aligned}
& M_{\text {in } B C 2}=M_{B C 2-c a r .}+M_{B C 2-s l .}+M_{\text {sorbed } B C 2}+M_{\text {outBC2 }} \quad \text { or } \\
& \left(C_{\text {in }}+Q_{R}\right) C_{o u t, B C 1}=k_{\text {bio-car2 }} X_{c a r 2} V C_{o u t, B C 2}+k_{\text {bio-sl2 }} X_{s l 2} V C_{o u t, B C 2}+\frac{\left(X_{s l 2} V K_{d} C_{o u t, B C 2}\right)}{S R T}+ \\
& \left(Q_{\text {in }}+Q_{R}\right) C_{\text {out }, B C 2}
\end{aligned}
$$

Whereas $k_{\text {bio-car. }}$ and $k_{\text {bio-sl. }}$ are the normalized biodegradation constants for attached and suspended biomass, respectively $\left(\mathrm{L} \mathrm{g}^{-1} \mathrm{~d}^{-1}\right)$, as calculated in batch experiments for the loading conditions existing in the two reactors $(\mathrm{BC} 1$ and $\mathrm{BC} 2), X_{c a r}$ and $X_{s l}$. is the concentration of attached biomass on carriers and the concentration of MLSS, respectively $\left(\mathrm{g} \mathrm{L}^{-1}\right)$. Furthermore, $V$ is the volume of each reactor $\left(\mathrm{m}^{3}\right), K_{d}$ is the sludge-water distribution coefficient $\left(\mathrm{L} \mathrm{g}^{-1}\right)$, as calculated in a previous work [1] and SRT is the sludge residence time in the system (d). In both cases, the calculated amount of compound eliminated by each mechanism was compared to the initial amount of compound entering the system. 


\section{B. Transformation products identification}

The chromatographic separation was performed using a Thermo Acclaim RSLC C18, $2.2 \mu \mathrm{m}$ $120 \AA, 2.1 \times 100 \mathrm{~mm}$ column. The gradient program for both positive and negative mode is presented in Table S3. Methanol (solvent A) and water:methanol (90:10) (solvent B) both amended with $0.01 \%$ formic acid and $5 \mathrm{mM}$ ammonium formate was used as mobile phase for positive ionization and methanol and water:methanol (90:10) both amended with $5 \mathrm{mM}$ ammonium acetate as an eluent for negative ionization mode. A sodium formate solution (10 $\mathrm{mM}$ ) was always introduced between 0.1 to $0.3 \mathrm{~min}$ in the beginning of every chromatographic run through direct infusion at a flow rate of $50 \mu \mathrm{L} \mathrm{h}^{-1}$ to compensate for mass drifts and for internal mass calibration. Sodium formate solution was also used to perform daily external calibration in QTOFMS. The sodium formate calibration mixture consists of $10 \mathrm{mM}$ sodium formate in a mixture of water/isopropanol (1:1).

The QToF mass spectrometer was equipped with an electrospray ionization interface (ESI) operating both in positive and negative ionization mode. Operation parameters were: capillary voltage, $2500 \mathrm{~V}$; end plate offset, $500 \mathrm{~V}$; nebulizer pressure, 2 bar $\left(\mathrm{N}_{2}\right)$; drying gas, $8 \mathrm{~L} \mathrm{~min}{ }^{-1}$ $\left(\mathrm{N}_{2}\right)$; and drying temperature, $200{ }^{\circ} \mathrm{C}$. Data were acquired through broad-band collision induced dissociation (bbCID) mode, providing MS and MS/MS spectra simultaneously under positive and negative electrospray ionization (two separate runs). HR-MS data was recorded within a mass-to-charge $(\mathrm{m} / \mathrm{z})$ range of $50-1000$ for each sample, at $2 \mathrm{~Hz}$ spectra rate and at a continuously alternatively collision energy of $4 \mathrm{eV}$ (low energy, LE) and $25 \mathrm{eV}$ (high energy, $\mathrm{HE}$ ) in the collision cell Q2, for full-scan and MS/MS data, respectively. For masses corresponding to plausible transformation products (TPs), the fragmentation performed in Auto MS/MS mode with an inclusion list. For masses corresponding to the detected plausible 
transformation products (TPs), MS/MS spectra was subsequently acquired with data dependent acquisition in Auto MS/MS mode with an inclusion list.

Two generations of TPs for each BTR and $\mathrm{OH}-\mathrm{BTH}$ were predicted. MetabolitePredict (Bruker, Bremen, Germany), was also used for the prediction of possible phase I \& II metabolites as well as cytochrome P450 metabolites, to extend the possible candidates for screening [2]. For instance, monohydroxylation of benzotriazoles is not predicted by EAWAGPPS, but it is predicted by MetabolitePredict software. Finally, already known and reported metabolites from the literature were added to the database $[3,4]$.

For TPs' identification, the samples were screened for the exact masses of potential TPs according to a suspect database that was compiled by the online pathway prediction system hosted by EAWAG institute (EAWAG-PPS) without the "relative reasoning mode". A dataprocessing software (TargetAnalysis 1.3, Bruker) was used for the suspect screening of plausible transformation products. All the time interval samples were screened, in both positive and negative ionization modes, for the determination of suspect TPs from the database. The characterization of an exact mass as a possible TP was based on the following criteria, deltaRT $\leq$ $0.10 \mathrm{~min}$, mass error $\leq 5 \mathrm{ppm}$, isotopic fit: $\leq 1000 \mathrm{mSigma}$, intensity threshold $>500$ (+ESI) and $>200$ (-ESI) as well as, absence from the blank samples and occurrence of a time trend [5]. The potential TPs were subjected to MS/MS experiments via AutoMS mode with an inclusion list in order to obtain the MS/MS spectra and the fragments for further assignment of molecular formulas and structure elucidation. The SmartFormula algorithm was used to apply the sum formulae of the protonated or deprotonated ion and fragments (mass error and isotopic fit was also calculated). SmartFormula uses element restrictions for $\mathrm{C}, \mathrm{H}, \mathrm{N}$ and $\mathrm{O},[\mathrm{M} \pm \mathrm{H}]^{ \pm}$for positive and negative ion mode, mass tolerance of $5 \mathrm{ppm}$, the hydrogen to carbon ratio $(\mathrm{H} / \mathrm{C})$ ranges from 
0 to 3, it checks for ring and double bonds and allows even electron configuration for the MS peaks and both odd and even electron configuration for MS/MS peaks. 


\section{Supplementary Tables and Figures}

Table S1: Operational parameters of the HMBBR system used in this study and the AS and pure MBBR system used by Mazioti et al. (2015b).

\begin{tabular}{|c|c|c|c|c|c|c|c|c|}
\hline \multicolumn{9}{|c|}{ Hybrid Moving Bed Bioreactor System (examined in this study) } \\
\hline \multirow{2}{*}{$\begin{array}{l}\text { Continuous } \\
\text { flow system }\end{array}$} & \multirow{2}{*}{$\begin{array}{l}\text { Days of } \\
\text { operation }\end{array}$} & \multirow{2}{*}{$\begin{array}{l}\text { SRT } \\
\text { (days) }\end{array}$} & \multicolumn{2}{|c|}{$\begin{array}{l}\text { HRT } \\
\text { (hours) }\end{array}$} & \multicolumn{2}{|c|}{$\begin{array}{l}\text { Organic Loading } \\
\qquad\left(\mathrm{kg} \mathrm{m}^{-3} \mathrm{~d}^{-1}\right)\end{array}$} & \multicolumn{2}{|c|}{$\begin{array}{c}\text { Bioreactor Capacity } \\
\text { (L) }\end{array}$} \\
\hline & & & $\mathrm{BC} 1^{1}$ & $\mathrm{BC} 2^{2}$ & $\mathrm{BC} 1^{1}$ & $\mathrm{BC} 2^{2}$ & $\mathrm{BC} 1^{1}$ & $\mathrm{BC} 2^{2}$ \\
\hline $\begin{array}{r}\text { HMBBR } \\
(\mathrm{n}=11)\end{array}$ & 34 & 8 & $\begin{array}{c}12.4 \\
( \pm 0.13)\end{array}$ & $\begin{array}{c}12.4 \\
( \pm 0.6)\end{array}$ & $\begin{array}{c}0.64 \\
( \pm 0.39)\end{array}$ & $\begin{array}{c}0.11 \\
( \pm 0.09)\end{array}$ & 3 & 3 \\
\hline \multicolumn{9}{|c|}{ Activated Sludge System (examined in previous study) } \\
\hline $\begin{array}{l}\text { Continuous } \\
\text { flow system }\end{array}$ & $\begin{array}{l}\text { Days of } \\
\text { operation }\end{array}$ & $\begin{array}{l}\text { SRT } \\
\text { (days) }\end{array}$ & \multicolumn{2}{|c|}{$\begin{array}{l}\text { HRT } \\
\text { (hours) }\end{array}$} & \multicolumn{2}{|c|}{$\begin{array}{l}\text { Organic Loading } \\
\qquad\left(\mathrm{kg} \mathrm{m}^{-3} \mathrm{~d}^{-1}\right)\end{array}$} & \multicolumn{2}{|c|}{$\begin{array}{c}\text { Bioreactor Capacity } \\
\text { (L) }\end{array}$} \\
\hline $\begin{array}{c}\text { AS } \\
(n=16)\end{array}$ & 31 & 18 & \multicolumn{2}{|c|}{$26.4( \pm 2.4)$} & \multicolumn{2}{|c|}{$0.25( \pm 0.16)$} & \multicolumn{2}{|c|}{4.5} \\
\hline \multicolumn{9}{|c|}{ Moving Bed Bioreactor System (examined in previous study) } \\
\hline \multirow[t]{2}{*}{$\begin{array}{l}\text { Continuous } \\
\text { flow system }\end{array}$} & \multirow[t]{2}{*}{$\begin{array}{c}\text { Days of } \\
\text { operation }\end{array}$} & $\begin{array}{l}\text { SRT } \\
\text { (days) }\end{array}$ & \multicolumn{2}{|c|}{$\begin{array}{l}\text { HRT } \\
\text { (hours) }\end{array}$} & \multicolumn{2}{|c|}{$\begin{array}{l}\text { Organic Loading } \\
\qquad\left(\mathrm{kg} \mathrm{m}^{-3} \mathrm{~d}^{-1}\right)\end{array}$} & \multicolumn{2}{|c|}{$\begin{array}{c}\text { Bioreactor Capacity } \\
\text { (L) }\end{array}$} \\
\hline & & & $\mathrm{BC} 1^{1}$ & $\mathrm{BC} 2^{2}$ & $\mathrm{BC} 1^{1}$ & $\mathrm{BC}^{2}$ & $\mathrm{BC} 1^{1}$ & $\mathrm{BC} 2^{2}$ \\
\hline $\begin{array}{l}\text { MBBR-low } \\
\quad(\mathrm{n}=15)\end{array}$ & 45 & $\infty$ & $\begin{array}{c}26.4 \\
( \pm 3.6)\end{array}$ & $\begin{array}{c}26.4 \\
( \pm 3.6)\end{array}$ & $\begin{array}{c}0.25 \\
( \pm 0.16)\end{array}$ & $\begin{array}{c}0.05 \\
( \pm 0.03)\end{array}$ & 4.5 & 4.5 \\
\hline $\begin{array}{l}\text { MBBR-high } \\
\quad(\mathrm{n}=11)\end{array}$ & 45 & $\infty$ & $\begin{array}{c}10.8 \\
( \pm 1.2)\end{array}$ & $\begin{array}{c}10.8 \\
( \pm 1.2)\end{array}$ & $\begin{array}{c}0.60 \\
( \pm 0.4)\end{array}$ & $\begin{array}{c}0.17 \\
( \pm 0.11)\end{array}$ & 4.5 & 4.5 \\
\hline
\end{tabular}

${ }^{1} \mathrm{BC} 1$ : bioreactor with biocarriers $1 ;{ }^{2} \mathrm{BC}$ : bioreactor with biocarriers 2 
Table S2. Characteristics of raw and treated wastewater in HMBBR system used in this study (n $=10$, standard deviations are given in parentheses).

\begin{tabular}{|c|c|c|}
\hline Parameter & Raw wastewater & Treated wastewater \\
\hline $\mathrm{pH}$ & $7.0( \pm 0.4)$ & $7.0( \pm 0.2)$ \\
\hline $\mathrm{COD}_{\mathrm{dis}}\left(\mathrm{mg} \mathrm{L}^{-1}\right)$ & $322( \pm 193)$ & $24( \pm 14)$ \\
\hline $\mathrm{NH}_{4}-\mathrm{N}\left(\mathrm{mg} \mathrm{L}^{-1}\right)$ & $81( \pm 35)$ & $1.1( \pm 1.1)$ \\
\hline $\mathrm{NO}_{3}-\mathrm{N}\left(\mathrm{mg} \mathrm{L}^{-1}\right)$ & $5.1( \pm 4.0)$ & $35( \pm 19)$ \\
\hline $\mathrm{TSS}^{\left(\mathrm{mg} \mathrm{L}^{-1}\right)}$ & $76( \pm 66)$ & $12.3( \pm 9.2)$ \\
\hline
\end{tabular}

Table S3: Initial conditions applied in batch biodegradation experiments with different types of biomass from bioreactors $\mathrm{BC} 1$ and $\mathrm{BC} 2$.

\begin{tabular}{|c|c|c|c|c|}
\hline Parameter & BC1 carriers & BC1 sludge & BC2 carriers & BC2 sludge \\
\hline $\mathrm{pH}$ & 7.02 & 7.18 & 7.04 & 7.22 \\
\hline $\mathrm{TSS}\left(\mathrm{mg} \mathrm{L}^{-1}\right)$ & 1158 & 3382 & 776 & 3739 \\
\hline $\mathrm{NH}_{4}-\mathrm{N}\left(\mathrm{mg} \mathrm{L}^{-1}\right)$ & 53 & 55 & 8.5 & 9.7 \\
\hline $\mathrm{NO}_{3}-\mathrm{N}\left(\mathrm{mg} \mathrm{L}^{-1}\right)$ & 2.5 & 1.8 & 7.4 & 6.8 \\
\hline $\mathrm{COD}_{\mathrm{dis}}\left(\mathrm{mg} \mathrm{L}^{-1}\right)$ & 203 & 223 & 28 & 59 \\
\hline
\end{tabular}


Table S4: Elution program concerning the analysis of samples for the determination of transformation products (TPs). The gradient program starts with $1 \%$ A constant for 1 min and it increases to $39 \%$ in $2 \mathrm{~min}$, and then to $99.9 \%$ in the following $11 \mathrm{~min}$. Then it keeps constant for $2 \mathrm{~min}$ and finally initial conditions were restored within $0.1 \mathrm{~min}$. Gradient was also applied in the flow rate, starting with $0.2 \mathrm{~mL} \mathrm{~min}^{-1}$ for 1 min, increasing to $0.4 \mathrm{~mL} \mathrm{~min}^{-1}$ in $13 \mathrm{~min}$ and to $0.48 \mathrm{~mL} \mathrm{~min}^{-1}$ in $2 \mathrm{~min}$. Then it keeps constant for $3 \mathrm{~min}$ and then the initial flow rate is restored.

\begin{tabular}{|c|c|c|c|}
\hline \multicolumn{4}{|c|}{ Reverse Phase Chromatography } \\
\hline Time (min) & Flow rate (mL/min) & \%A* & \%B* \\
\hline 0.0 & 0.200 & 1.0 & 99.0 \\
\hline 0.1 & 0.200 & 1.0 & 99.0 \\
\hline 1.0 & 0.200 & & 99.0 \\
\hline 3.0 & & 39.0 & 61.0 \\
\hline 14.0 & 0.400 & 99.9 & 0.1 \\
\hline 16.0 & 0.480 & 99.9 & 0.1 \\
\hline 16.1 & 0.480 & 1.0 & 99.0 \\
\hline 19.0 & 0.480 & 1.0 & 99.0 \\
\hline 19.1 & 0.200 & 1.0 & 99.0 \\
\hline 20 & 0.2 & 1.0 & 99.0 \\
\hline
\end{tabular}

*Methanol (solvent A) and water:methanol (90:10) (solvent B) 
Table S5: Performance of the HMBBR system used in this study and the AS and pure MBBR system used by Mazioti et al. (2015b).

\begin{tabular}{|c|c|c|c|c|c|c|c|c|c|c|c|c|c|}
\hline \multicolumn{14}{|c|}{ Hybrid Moving Bed Bioreactor System (examined in this study) } \\
\hline \multirow{3}{*}{$\begin{array}{l}\text { Continuous } \\
\text { flow system }\end{array}$} & \multirow{3}{*}{$\begin{array}{l}\text { Days of } \\
\text { operation }\end{array}$} & \multirow{2}{*}{\multicolumn{2}{|c|}{$\begin{array}{l}\text { Attached Biomass } \\
\qquad\left(\mathrm{mg} \mathrm{L}^{-1}\right)\end{array}$}} & \multirow{3}{*}{$\begin{array}{c}\begin{array}{c}\text { MLSS } \\
\left(\mathrm{mg} \mathrm{L}^{-1}\right)\end{array} \\
\mathrm{BCl}^{3}\end{array}$} & \multirow{3}{*}{$\begin{array}{c}\begin{array}{c}\text { MLSS } \\
\left(\mathrm{mg} \mathrm{L}^{-1}\right)\end{array} \\
\mathrm{BC}^{4}\end{array}$} & \multirow{2}{*}{\multicolumn{2}{|c|}{$\mathrm{pH}$}} & \multicolumn{6}{|c|}{ Removal \% } \\
\hline & & & & & & & & \multicolumn{3}{|c|}{ COD dissolved } & \multicolumn{3}{|c|}{$\mathrm{NH}_{4}-\mathrm{N}$} \\
\hline & & $\mathrm{BC}^{3}$ & $\mathrm{BC} 2^{4}$ & & & $\mathrm{BC}^{3}$ & $\mathrm{BC} 2^{4}$ & $\mathrm{BC} 1^{3}$ & $\mathrm{BC} 2^{4}$ & Total $^{5}$ & $\mathrm{BC} 1^{3}$ & $\mathrm{BC} 2^{4}$ & Total $^{5}$ \\
\hline $\begin{array}{r}\text { HMBBR } \\
(\mathrm{n}=11)\end{array}$ & 34 & $\begin{array}{c}1023 \\
( \pm 171)\end{array}$ & $\begin{array}{c}610 \\
( \pm 203)\end{array}$ & $\begin{array}{c}2914 \\
( \pm 510)\end{array}$ & $\begin{array}{c}2687 \\
( \pm 524)\end{array}$ & $\begin{array}{c}7.0 \\
( \pm 0.1)\end{array}$ & $\begin{array}{c}7.0 \\
( \pm 0.2)\end{array}$ & $\begin{array}{c}80 \\
( \pm 16)\end{array}$ & $\begin{array}{c}63 \\
( \pm 37)\end{array}$ & $\begin{array}{c}87 \\
( \pm 8)\end{array}$ & $\begin{array}{c}89 \\
( \pm 11)\end{array}$ & $\begin{array}{c}61 \\
( \pm 28)\end{array}$ & $\begin{array}{c}98 \\
( \pm 2)\end{array}$ \\
\hline \multicolumn{14}{|c|}{ Activated Sludge System (examined in previous study) } \\
\hline \multirow{3}{*}{$\begin{array}{l}\text { Continuous } \\
\text { flow system }\end{array}$} & \multirow{3}{*}{$\begin{array}{l}\text { Days of } \\
\text { operation }\end{array}$} & & & \multirow{2}{*}{$\begin{array}{c}\text { MLSS } \\
\left(\mathrm{mg} \mathrm{L}^{-1}\right)\end{array}$} & \multirow{2}{*}{$\begin{array}{c}\mathrm{TSS} \\
\left(\mathrm{mg} \mathrm{L}^{-1}\right)\end{array}$} & \multirow{2}{*}{\multicolumn{2}{|c|}{$\mathrm{pH}$}} & \multicolumn{6}{|c|}{ Removal \% } \\
\hline & & & & & & & & \multicolumn{3}{|c|}{ COD dissolved } & \multicolumn{3}{|c|}{$\mathrm{NH}_{4}-\mathrm{N}$} \\
\hline & & & & $\mathrm{AB}^{1}$ & $\mathrm{Out}^{2}$ & $\mathrm{AB}^{1}$ & Out $^{2}$ & \multicolumn{3}{|c|}{$\mathrm{AB}$} & \multicolumn{3}{|c|}{$\mathrm{AB}$} \\
\hline $\begin{array}{c}\text { AS } \\
(n=16)\end{array}$ & 31 & & & $\begin{array}{c}2370 \\
( \pm 590)\end{array}$ & $\begin{array}{c}11 \\
( \pm 13)\end{array}$ & $\begin{array}{c}7.2 \\
( \pm 0.4)\end{array}$ & $\begin{array}{c}7.3 \\
( \pm 0.6)\end{array}$ & \multicolumn{3}{|c|}{$90( \pm 7)$} & \multicolumn{3}{|c|}{$93( \pm 12)$} \\
\hline
\end{tabular}

\begin{tabular}{|c|c|c|c|c|c|c|c|c|c|c|c|c|c|}
\hline \multicolumn{14}{|c|}{ Moving Bed Bioreactor System (examined in previous study) } \\
\hline \multirow{3}{*}{$\begin{array}{l}\text { Continuous } \\
\text { flow system }\end{array}$} & \multirow{3}{*}{$\begin{array}{l}\text { Days of } \\
\text { operation }\end{array}$} & \multirow{2}{*}{\multicolumn{2}{|c|}{$\begin{array}{l}\text { Attached Biomass } \\
\qquad\left(\mathrm{mg} \mathrm{L}^{-1}\right)\end{array}$}} & \multirow{3}{*}{$\begin{array}{c}\begin{array}{c}\text { MLSS } \\
\left(\mathrm{mg} \mathrm{L}^{-1}\right)\end{array} \\
\mathrm{BCl}^{3}\end{array}$} & \multirow{3}{*}{$\begin{array}{c}\begin{array}{c}\text { MLSS } \\
\left(\mathrm{mg} \mathrm{L}^{-1}\right)\end{array} \\
\mathrm{BC}^{4}\end{array}$} & \multirow{2}{*}{\multicolumn{2}{|c|}{$\mathrm{pH}$}} & \multicolumn{6}{|c|}{ Removal \% } \\
\hline & & & & & & & & \multicolumn{3}{|c|}{ COD dissolved } & \multicolumn{3}{|c|}{$\mathrm{NH}_{4}-\mathrm{N}$} \\
\hline & & $\mathrm{BC}^{3}$ & $\mathrm{BC} 2^{4}$ & & & $\mathrm{BC} 1^{3}$ & $\mathrm{BC}^{4}$ & $\mathrm{BCl}^{3}$ & $\mathrm{BC} 2^{4}$ & Total $^{5}$ & $\mathrm{BC}^{3}$ & $\mathrm{BC} 2^{4}$ & Total $^{5}$ \\
\hline $\begin{array}{l}\text { MBBR-low } \\
(\mathrm{n}=15)\end{array}$ & 45 & 726 & 100 & $\begin{array}{c}195 \\
( \pm 81)\end{array}$ & $\begin{array}{c}131 \\
( \pm 89)\end{array}$ & $\begin{array}{c}7.0 \\
( \pm 0.5)\end{array}$ & $\begin{array}{c}6.8 \\
( \pm 0.9)\end{array}$ & $\begin{array}{c}81 \\
( \pm 13)\end{array}$ & $\begin{array}{c}42 \\
( \pm 26)\end{array}$ & $\begin{array}{c}86 \\
( \pm 11)\end{array}$ & $\begin{array}{c}78 \\
( \pm 29)\end{array}$ & $\begin{array}{c}84 \\
( \pm 23)\end{array}$ & $\begin{array}{c}93 \\
( \pm 13)\end{array}$ \\
\hline $\begin{array}{l}\text { MBBR-high } \\
\quad(\mathrm{n}=11)\end{array}$ & 45 & $\begin{array}{c}1079 \\
( \pm 715)\end{array}$ & $\begin{array}{c}312 \\
( \pm 108)\end{array}$ & $\begin{array}{c}138 \\
( \pm 68)\end{array}$ & $\begin{array}{c}124 \\
( \pm 68)\end{array}$ & $\begin{array}{c}7.4 \\
( \pm 0.2)\end{array}$ & $\begin{array}{c}7.2 \\
( \pm 0.3)\end{array}$ & $\begin{array}{c}72 \\
( \pm 11)\end{array}$ & $\begin{array}{c}67 \\
( \pm 21)\end{array}$ & $\begin{array}{c}91 \\
( \pm 7)\end{array}$ & $\begin{array}{c}73 \\
( \pm 24)\end{array}$ & $\begin{array}{c}87 \\
( \pm 21)\end{array}$ & $\begin{array}{c}95 \\
( \pm 7)\end{array}$ \\
\hline
\end{tabular}

${ }^{1} \mathrm{AB}$ : aerobic bioreactor with activated sludge; ${ }^{2} \mathrm{Out}$ : treated wastewater; ${ }^{3} \mathrm{BC} 1$ : bioreactor with biocarriers $1 ;{ }^{4} \mathrm{BC} 2$ : bioreactor with biocarriers2;

${ }^{5}$ Total: Total Removal in $\mathrm{BC} 1$ and $\mathrm{BC} 2$ 
Table S6: Biodegradation constants calculated during batch experiments with biocarriers and activated sludge (AS) from $1^{\text {st }}$ bioreactor $(\mathrm{BC} 1)$ and $2^{\text {nd }}$ bioreactor $(\mathrm{BC} 2)$ (average values and standard deviation).

\begin{tabular}{|c|c|c|c|c|c|c|c|c|c|c|c|c|c|c|c|c|c|c|c|}
\hline \multicolumn{20}{|c|}{ Biodegradation rate constant, $\mathrm{k}\left(\mathrm{d}^{-1}\right)$} \\
\hline $\begin{array}{c}\text { Experi } \\
\text { ment }\end{array}$ & type & average & st. dev. & $\mathrm{R}^{2}$ & average & st.dev. & $\mathrm{R}^{2}$ & average & st.dev. & $\mathrm{R}^{2}$ & average & st.dev. & $\mathrm{R}^{2}$ & average & st.dev. & $\mathrm{R}^{2}$ & average & st.dev. & $\mathrm{R}^{2}$ \\
\hline & & \multicolumn{3}{|c|}{ ОНВТН } & \multicolumn{3}{|c|}{ BTR } & \multicolumn{3}{|c|}{ XTR } & \multicolumn{3}{|c|}{ CBTR } & \multicolumn{3}{|c|}{ 5TTR } & \multicolumn{3}{|c|}{ 4TTR } \\
\hline $\mathrm{BCl}^{1}$ & carriers & 2.43 & 1.34 & 0.902 & 0.29 & 0.08 & 0.971 & 0.31 & 0.11 & 0.950 & 0.75 & 0.34 & 0.935 & 0.23 & 0.45 & 0.392 & \multicolumn{3}{|c|}{ N.A. } \\
\hline $\mathrm{BCl}^{2}$ & sludge & 25.22 & 1.57 & 0.985 & 1.54 & 0.26 & 0.984 & 0.98 & 0.33 & 0.925 & 0.81 & 0.13 & 0.991 & 0.34 & 0.17 & 0.914 & 0.09 & 0.06 & 0.669 \\
\hline $\mathrm{BC} 2^{3}$ & carriers & 1.17 & 0.17 & 0.985 & 0.19 & 0.18 & 0.742 & 0.27 & 0.20 & 0.637 & 0.40 & 0.33 & 0.774 & 0.17 & 0.30 & 0.421 & 0.27 & 1.05 & 0.735 \\
\hline $\mathrm{BC} 2^{4}$ & sludge & 4.84 & 1.17 & 0.997 & 0.63 & 0.20 & 0.916 & 0.26 & 0.12 & 0.921 & 0.68 & 0.23 & 0.959 & 0.79 & 0.57 & 0.841 & 0.08 & 0.17 & 0.897 \\
\hline \multicolumn{20}{|c|}{ Pseudo first-order biodegradation rate constant, $k_{b i o}\left(L_{g s s}{ }^{-1} d^{-1}\right)$} \\
\hline $\begin{array}{c}\text { Experi } \\
\text { ment }\end{array}$ & type & average & st. dev. & $\mathrm{R}^{2}$ & average & st.dev. & $\mathrm{R}^{2}$ & average & st.dev. & $\mathrm{R}^{2}$ & average & st.dev. & $\mathrm{R}^{2}$ & average & st.dev. & $\mathrm{R}^{2}$ & average & st.dev. & $\mathrm{R}^{2}$ \\
\hline & & \multicolumn{3}{|c|}{ ОНВТН } & \multicolumn{3}{|c|}{ BTR } & \multicolumn{3}{|c|}{ XTR } & \multicolumn{3}{|c|}{ CBTR } & \multicolumn{3}{|c|}{ 5TTR } & \multicolumn{3}{|c|}{ 4TTR } \\
\hline $\mathrm{BC} 1^{1}$ & carriers & 2.09 & 1.15 & 0.902 & 0.25 & 0.07 & 0.971 & 0.27 & 0.10 & 0.950 & 0.65 & 0.29 & 0.935 & 0.20 & 0.39 & 0.392 & \multicolumn{3}{|c|}{ N.A. } \\
\hline $\mathrm{BCl}^{2}$ & sludge & 7.46 & 0.46 & 0.985 & 0.46 & 0.08 & 0.984 & 0.29 & 0.10 & 0.925 & 0.24 & 0.04 & 0.991 & 0.10 & 0.05 & 0.914 & 0.03 & 0.02 & 0.669 \\
\hline $\mathrm{BC} 2^{3}$ & carriers & 1.51 & 0.22 & 0.985 & 0.24 & 0.23 & 0.742 & 0.35 & 0.25 & 0.637 & 0.51 & 0.43 & 0.774 & 0.22 & 0.39 & 0.421 & 0.35 & 1.36 & 0.735 \\
\hline $\mathrm{BC} 2^{4}$ & sludge & 1.29 & 0.31 & 0.997 & 0.17 & 0.05 & 0.916 & 0.07 & 0.03 & 0.921 & 0.18 & 0.06 & 0.959 & 0.21 & 0.15 & 0.841 & 0.02 & 0.05 & 0.897 \\
\hline
\end{tabular}


${ }^{1}$ Experiments with biocarriers from $\mathrm{BC} 1$ were conducted with $\mathrm{COD}$ initial concentration of $203 \mathrm{mg} \mathrm{L}^{-1}$; ${ }^{2}$ Experiments with AS from BC1 were conducted with COD initial concentration of $223 \mathrm{mg} \mathrm{L} 1{ }^{3}$ Experiments with biocarriers from $\mathrm{BC} 2$ were conducted with COD initial concentration of $28 \mathrm{mg} \mathrm{L}^{-1}$; ${ }^{4}$ Experiments with AS from BC2 were conducted with COD initial concentration of $59 \mathrm{mg} \mathrm{L}^{-1}$. 
a)

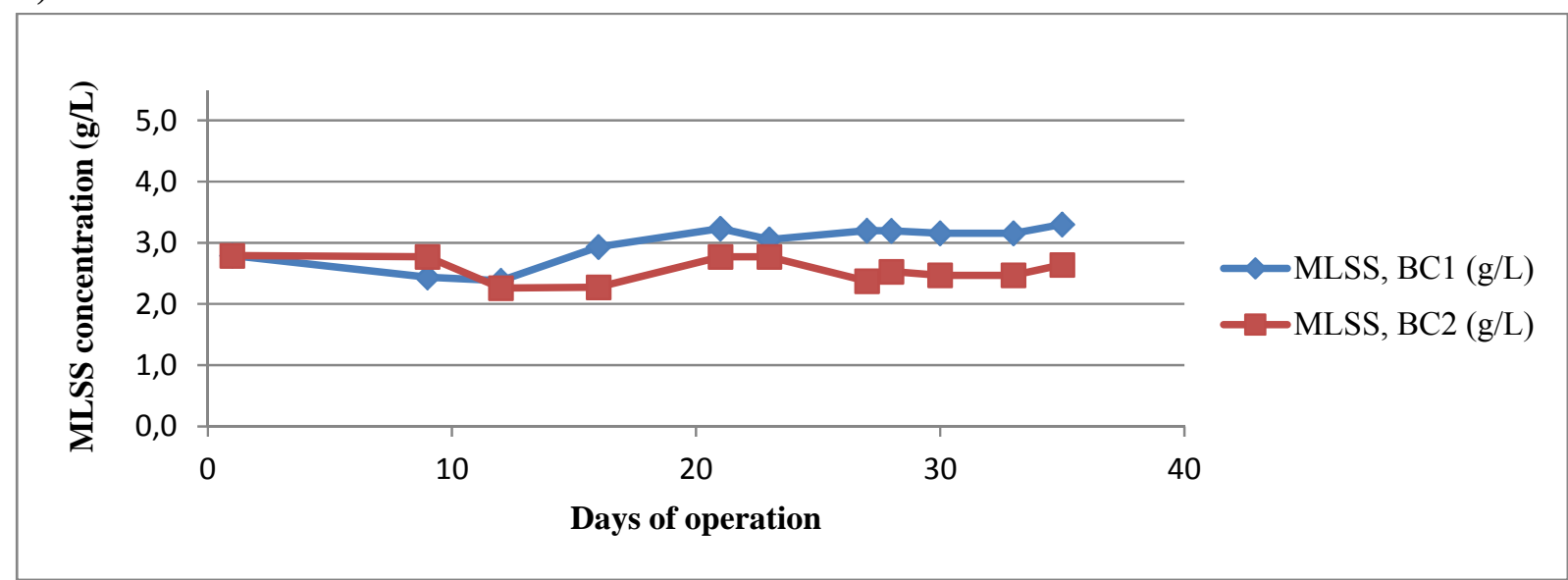

b)

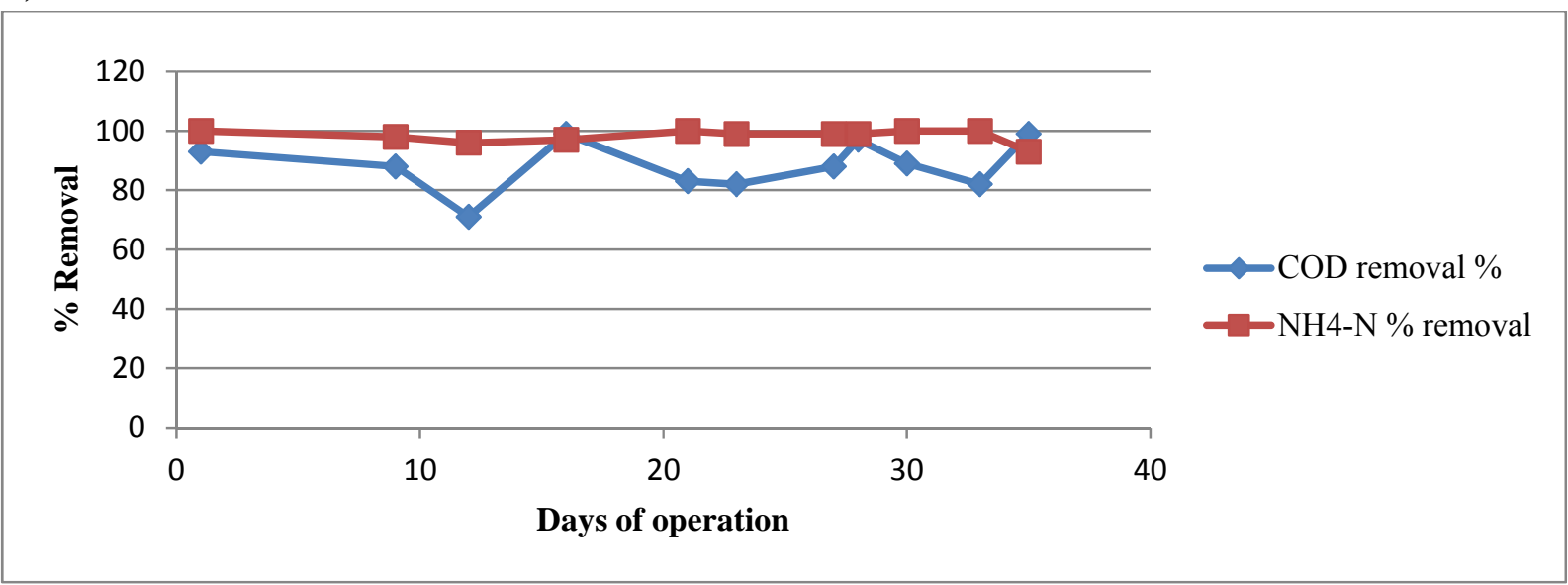

Figure S1. MLSS concentrations (a) and dissolved COD and $\mathrm{NH}_{4}-\mathrm{N}$ removal (b) during the phase of acclimatization (1-27 days) and the experimental period (28-35 days) of the study.

\section{References}

[1] Mazioti, A.A., Stasinakis, A.S., Gatidou, G., Thomaidis, N.S., Andersen, H.R., 2015a. Sorption and biodegradation of selected benzotriazoles and hydroxybenzothiazole in activated sludge and estimation of their fate during wastewater treatment Chemosphere $131,117-123$.

[2] Bletsou, A.A., Jeon, J., Hollender, J, Archontaki, E., Thomaidis, N.S., 2015. Targeted and non-targeted liquid chromatography-mass spectrometric workflows for identification 
of transformation products of emerging pollutants in the aquatic environment, $\operatorname{TrAC}$ Trends in Analytical Chemistry 66, 32-44.

[3] Liu, Y.-S., Ying, G.-G., Shareef, A., Kookana, R.S., 2011. Biodegradation of three selected benzotriazoles under aerobic and anaerobic conditions. Water Research 45, 50055014.

[4] Huntscha, S., Hofstetter, T.B., Schymanski, E.L., Spahr, S., Hollender, J. 2014. Biotransformation of benzotriazoles: Insights from transformation product identification and compound-specific isotope analysis. Environmental Science and Technology 48, 44354443.

[5] Li, Z., Maier, M.P.,Radke,M., 2013, Screening for pharmaceutical transformation products formed in river sediment by combining ultrahigh performance liquidchromatography/high resolution mass spectrometry with a rapid dataprocessing method, AnalyticaChimicaActa 810, 61-70.

[6] Mazioti A.A., Stasinakis A.S., Pantazi Y., Andersen H.R., 2015b. Biodegradation of benzotriazoles and hydroxy-benzothiazole in wastewater by activated sludge and moving bed biofilm reactor systems. Bioresource Technology 192, 627-635. 